Electronic Supplementary Information

for

\title{
Underlining the importance of peripheral protic functional groups to enhance the proton exchange of Gd-based MRI contrast agents.
}

Mariangela Boccalon, ${ }^{a}$ Loredana Leone, ${ }^{b}$ Giuseppe Marino, ${ }^{a}$ Nicola Demitri, ${ }^{c}$ Zsolt Baranyai, ${ }^{a *}$ Lorenzo Tei ${ }^{b *}$

${ }^{\text {a }}$ Bracco Research Centre, Bracco Imaging S.p.A. Via Ribes 5, 10010, Colleretto Giacosa, Italy.

b Dipartimento di Scienze e Innovazione Tecnologica, Università del Piemonte Orientale "A. Avogadro", Viale T. Michel 11, 15121 Alessandria, Italy.

${ }^{\mathrm{c}}$ Elettra-Sincrotrone Trieste, S.S. 14 Km 163.5 in Area Science Park, 34149 Basovizza - Trieste, Italy.

CONTENT:

1. Protonation and complexation equilibria of L1 and L2 pag. 2

$\begin{array}{ll}\text { 2. Kinetic inertness of GdL2 } & \text { pag. } 7\end{array}$

3. X-ray diffraction studies of $\left[\mathrm{Gd}(\mathrm{L} 2) \mathrm{H}_{-1}\left(\mathrm{OH}^{-}\right)\right]^{3-}$ complex $\quad$ pag. 9

4. ${ }^{1} \mathrm{H}$ and ${ }^{13} \mathrm{C}$ NMR spectra of protected and deprotected ligands $\quad$ pag. 16

$\begin{array}{ll}5 . \text { References } & \text { pag. } 23\end{array}$ 


\section{Protonation and complexation equilibria of L1 and L2:}

The protonation constants of $\mathrm{H}_{4} \mathrm{~L} 2$, defined by Eq. (S1), were determined by pH-potentiometry.

$$
\mathrm{K}_{\mathrm{i}}^{\mathrm{H}}=\frac{\left[\mathrm{H}_{\mathrm{i}} \mathrm{L}\right]}{\left[\mathrm{H}_{\mathrm{i}-1} \mathrm{~L}\right]\left[\mathrm{H}^{+}\right]}
$$

where $\mathrm{i}=1,2 \ldots 6$. The $\log K_{\mathrm{i}}^{\mathrm{H}}$ values of $\mathrm{L} 2$ obtained by $\mathrm{pH}$-potentiometry are listed and compared with those of $\mathrm{H}_{3} \mathrm{HPADO} 3 \mathrm{~A}, \mathrm{H}_{3} \mathrm{HPDO} 3 \mathrm{~A}, \mathrm{H}_{3} \mathrm{BT}-\mathrm{DO} 3 \mathrm{~A}$ and $\mathrm{H}_{4}$ DOTA (Scheme S1) in Table S1. Standard deviations $(3 \sigma)$ are shown in parentheses. By taking into account the protonation sequence of the macrocyclic DOTA-like ligands determined by spectroscopy and potentiometry methods, ${ }^{1-3}$ it is assumed that the first and second protonation of L2 occur at two opposite ring nitrogen atoms, whereas the third protonation process takes place at one of the carboxylate groups attached to the non-protonated ring nitrogen atoms. Fourth proton is localized on the carboxylate group of the 2hydroxypropanoic side chain, whereas further protonation of L2 occurs at the non-protonated carboxylate pendant arms. Comparison of the protonation constants (Table S1) reveals that the $\log K_{1}{ }^{\mathrm{H}}$ and $\log K_{2}{ }^{\mathrm{H}}$ values of L2, HPADO3A and BT-DO3A are comparable and significantly lower than that of HPDO3A and DOTA. In fact, equilibrium data characterizing the protonation of L1, L2, HPADO3A and BT-DO3A ligands were measured in the presence of $0.15 \mathrm{M}$ and $0.1 \mathrm{M} \mathrm{NaCl}$ ionic strength, whereas those of HPDO3A and DOTA complexes were obtained in $0.1 \mathrm{M} \mathrm{Me} 4 \mathrm{NCl}$ and 0.1 $\mathrm{M} \mathrm{KCl}$ solution, respectively. It is well known that DOTA derivatives form complexes with $\mathrm{Na}^{+}$ion $\left(\log K_{\mathrm{Na}(\mathrm{DOTA})}=4.38 ; \log K_{\mathrm{Na}(\mathrm{BT}-\mathrm{DO} 3 \mathrm{~A})}=2.32\right) .{ }^{4,5}$, which are clearly responsible for the lower $\log K_{1}{ }^{\mathrm{H}}$ and $\log K_{2}{ }^{\mathrm{H}}$ values of L2, HPADO3A and BT-DO3A ligands.

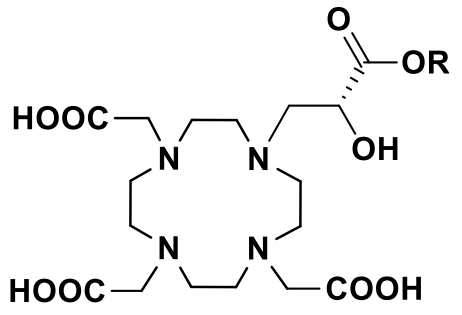

$\mathrm{R}=\mathrm{CH}_{3}: \mathbf{L 1}$

$\mathrm{R}=\mathrm{H}, \mathrm{L} 2$

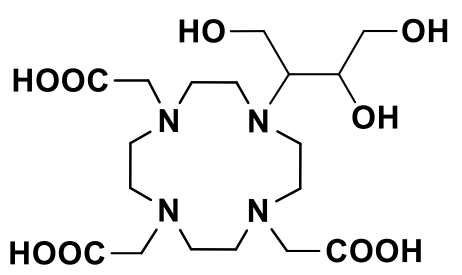

BT-D03A

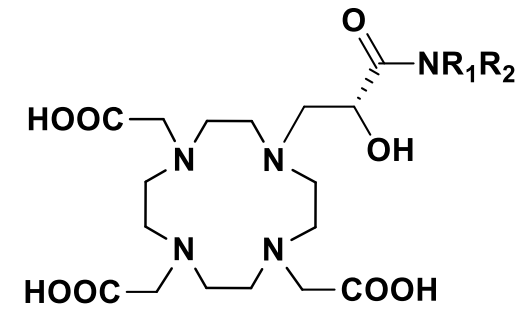

$\mathrm{R}_{1}=\mathrm{R}_{2}=\mathrm{H}:$ HPADO3A

$\mathrm{R}_{1}=\mathrm{Bn}, \mathrm{R}_{2}=\mathrm{H}$, BzHPADO $3 A$

$\mathrm{R}_{1}=\mathrm{R}_{2}=$ piperidine: PipHPADO3A

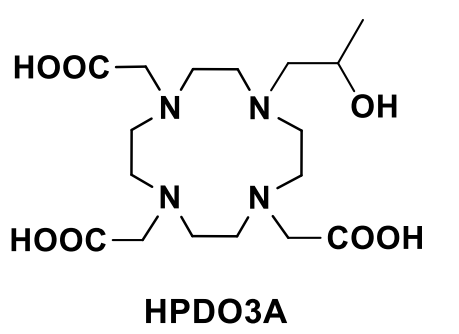

Scheme S1. Macrocyclic ligands discussed in the present work. 
The stability and protonation constants of $\mathrm{Ca}^{\mathrm{II}}-\mathrm{Zn}^{\mathrm{II}}$-, $\mathrm{Cu}^{\mathrm{II}}$ - and $\mathrm{Gd}^{\mathrm{III}}$-complexes of $\mathrm{L} 2$, expressed by Eqs. (S2) and (S3), were determined by pH-potentiometry and spectrophotometry at $25^{\circ} \mathrm{C}$ in $0.15 \mathrm{M}$ $\mathrm{NaCl}$ solution.

$$
\begin{gathered}
\mathrm{K}_{\mathrm{ML}}=\frac{[\mathrm{ML}]}{[\mathrm{M}][\mathrm{L}]} \\
\mathrm{K}_{\mathrm{MH}_{\mathrm{i}} \mathrm{L}}=\frac{\left[\mathrm{MH}_{\mathrm{i}} \mathrm{L}\right]}{\left[\mathrm{MH}_{\mathrm{i}-1} \mathrm{~L}\right]\left[\mathrm{H}^{+}\right]}
\end{gathered}
$$

where $\mathrm{i}=0,1,2,3$. The $K_{\mathrm{ML}}$ and $K_{\mathrm{MHiL}}$ values of $\mathrm{Ca}^{\mathrm{II}}-\mathrm{Zn}^{\mathrm{II}}$ - and $\mathrm{Cu}^{\mathrm{II}}-\mathrm{L} 2$ complexes were calculated from the $\mathrm{pH}$-potentiometric titration data obtained at 1:1 metal to ligand concentration ratios. In the calculations, the best fitting of the $\mathrm{mL} \mathrm{NaOH}-\mathrm{pH}$ data was obtained by assuming the formation of ML, MHL, $\mathrm{MH}_{2} \mathrm{~L}$ and $\mathrm{MH}_{3} \mathrm{~L}$ species. The stability constant of GdL2 was calculated from the equilibrium data obtained by the "out-of-cell" technique due to the slow complexation reaction.

The formation of lanthanide(III)-complexes with DOTA and DOTA derivatives takes place via the diprotonated "out-of-cage" intermediate species (e.g. ${ }^{*} \mathrm{Ln}\left(\mathrm{H}_{2} \mathrm{DOTA}\right)$ ), in which the $\mathrm{Ln}^{\mathrm{III}}$-ion is coordinated by the carboxylate groups, whereas two opposite ring nitrogens are protonated. ${ }^{6-10}$ Tipically, the formation of the "in cage" $\operatorname{Ln}($ DOTA)" and LnDOTA-like complexes occurs by the slow deprotonation of the ring nitrogens, which is followed by the penetration of the $\mathrm{Ln}^{\mathrm{III}}$-ion into the $\mathrm{N}$ and $\mathrm{O}$ donors coordination cage of the ligand. In order to calculate reliable equilibrium constants, the presence of the $\mathrm{Ln}\left(\mathrm{H}_{2} \mathrm{DOTA}\right)^{+}$intermediate, the free $\mathrm{Ln}^{3+}$ ion and the final $\mathrm{Ln}(\mathrm{DOTA})^{-}$ complex should be considered in the equilibrium $\mathrm{Ln}^{\mathrm{III}}$ - DOTA system. ${ }^{11,12}$ The formation and stability constant of the $* \mathrm{Ln}\left(\mathrm{H}_{2} \mathrm{~L}\right)$ intermediate is expressed by Eqs (S4) and (S5).

$$
\begin{gathered}
\mathrm{Ln}^{3+}+\mathrm{H}_{2} \mathrm{~L} \rightleftharpoons * \operatorname{Ln}\left(\mathrm{H}_{2} \mathrm{~L}\right) \\
{ }^{*} \mathrm{~K}_{\mathrm{Ln}\left(\mathrm{H}_{2} \mathrm{~L}\right)}=\frac{\left[\mathrm{Ln}\left(\mathrm{H}_{2} \mathrm{~L}\right)\right]}{\left[\mathrm{Ln}^{3+}\right]\left[\mathrm{H}_{2} \mathrm{~L}\right]}
\end{gathered}
$$

Since this out-of-cage intermediate is formed rapidly, the ${ }^{*} K_{\mathrm{Gd}(\mathrm{H} 2 \mathrm{~L})}$ stability constant of the intermediate ${ }^{*} \mathrm{Gd}\left(\mathrm{H}_{2} \mathrm{~L} 2\right)$ was calculated from the equilibrium data obtained by the direct $\mathrm{pH}$ potentiometric titration of $\mathrm{Gd}^{3+}-\mathrm{L} 2$ systems at 1:1 metal to ligand concentration ratios in the $\mathrm{pH}$ range $1.7-4.0$. On the other hand, the stability constant of GdL2 was calculated from the $\mathrm{mL} \mathrm{NaOH}$ - pH data of the "out-of-cell" samples, which had equilibrium $\mathrm{pH}$ values in the range of 2.0 - 4.0. For the complete characterization of the $\mathrm{Gd}^{3+}-\mathrm{L} 2$ system, the GdL2 complex (which is formed completely at about $\mathrm{pH}=3.5$ ) was titrated with $0.2 \mathrm{M} \mathrm{NaOH}$ solution in the $\mathrm{pH}$ range $3.5-12.0$. 
During these titrations, base consumption was observed at about $\mathrm{pH}>3.5$ and $\mathrm{pH}>8.0$, which indicated the deprotonation of the $\mathrm{Gd}(\mathrm{HL})$ and GdL species, respectively. These processes correspond the dissociation of $\mathrm{H}^{+}$ion from the carboxylate and the alcoholic -OH group of the 2-hydroxypropanoic pendant arm (Eqs. (S3) and (S4)). A pH-potentiometric titration of GdL1 complex with $0.2 \mathrm{M} \mathrm{NaOH}$ solution was also performed to determine the deprotonation constant of the hydroxyl group in the methyl 2-hydroxypropanoate pendant $\operatorname{arm}\left(\log K_{\mathrm{Gd}(\mathrm{L}) \mathrm{H}-1}\right.$, Table S1).

By taking into account the protonation constants of the ligand L2, the stability constant of the * $\mathrm{Gd}\left(\mathrm{H}_{2} \mathrm{~L} 2\right)$ intermediate and the stability and protonation constant of the GdL2 complex, the species distribution of the $\mathrm{Gd}^{3+}-\mathrm{L} 2$ system was calculated (Figure $\mathrm{S} 1$ ).

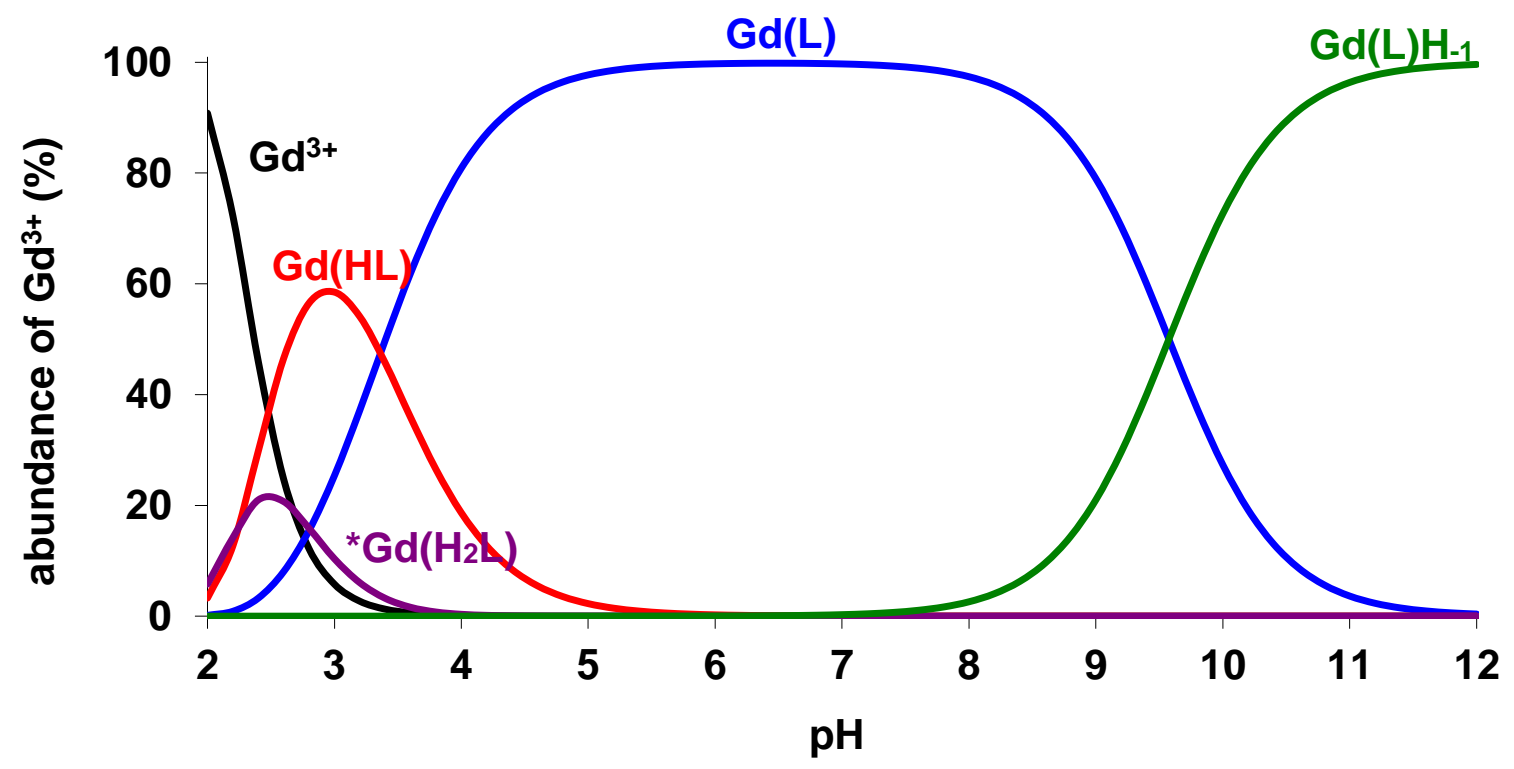

Figure S1. Species distribution diagram of the $\mathrm{Gd}^{3+}-\mathrm{L} 2$ system $\left(\left[\mathrm{Gd}^{3+}\right]=[\mathrm{L} 2]=1.0 \mathrm{mM}, 0,15 \mathrm{M}\right.$ $\mathrm{NaCl}, 298 \mathrm{~K})$

Then, the stability and protonation constants of CuL2 were determined by spectrophotometry. The equilibrium reaction (Eq. (S6)) was studied in the $\left[\mathrm{H}^{+}\right]$range of $0.01-1.0 \mathrm{M}$. The ionic strength of these samples was not constant at $\left[\mathrm{H}^{+}\right]>0.15 \mathrm{M}\left(\left[\mathrm{H}^{+}\right] \leq 0.15 \mathrm{M}, \mathrm{I}=\left[\mathrm{Na}^{+}\right]+\left[\mathrm{H}^{+}\right]=0.15 \mathrm{M}\right)$. In these sample the formation of $\mathrm{Cu}^{2+}, \mathrm{Cu}\left(\mathrm{H}_{2} \mathrm{~L}\right), \mathrm{Cu}\left(\mathrm{H}_{3} \mathrm{~L}\right)$ and $\mathrm{H}_{\mathrm{x}} \mathrm{L}$ species was assumed.

$$
\mathrm{Cu}^{2+}+\mathrm{H}_{\mathrm{x}} \mathrm{L} \rightleftharpoons\left[\mathrm{Cu}\left(\mathrm{H}_{\mathrm{x}-\mathrm{y}} \mathrm{L}\right)\right]+\mathrm{yH}^{+}
$$

where $\mathrm{x}=5$ and $6 ; \mathrm{y}=3$ and 4 . Some characteristic absorption spectra are shown in Figure S2. 


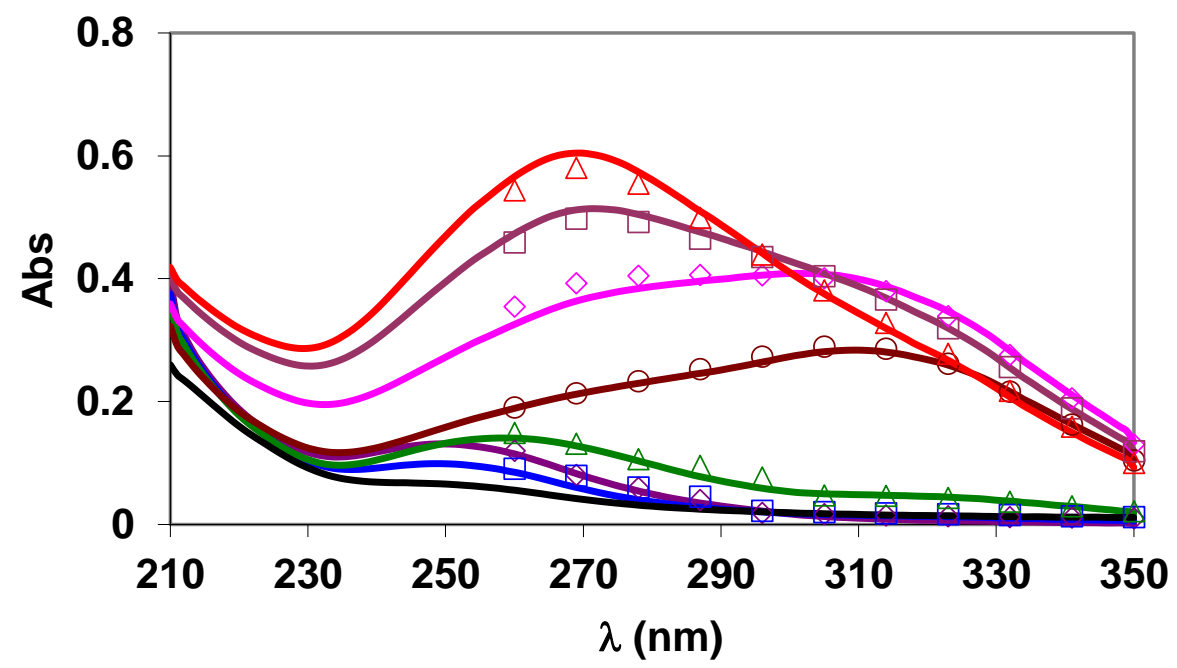

Figure S2. Absorbtion spectra of $\mathrm{Cu}^{2+}-\mathrm{L} 2$ system. The solid lines and the open symbols represent the experimental and the calculated absorbance values, respectively. $\left(\left[\mathrm{Cu}^{2+}\right]=[\mathrm{L} 2]=0.72 \mathrm{mM},\left[\mathrm{H}^{+}\right]=\right.$ $1.0(\square), 0,60(\diamond), 0.31(\triangle), 0.10(\bigcirc), 0.043(\diamond), 0.023(\square)$ and $0.011 \mathrm{M}(\triangle),\left[\mathrm{Cu}^{2+}\right]=\mathbf{0 . 7 2} \mathrm{mM}$, $\left.\mathrm{I}=\left[\mathrm{Na}^{+}\right]+\left[\mathrm{H}^{+}\right]=0.15,\left[\mathrm{H}^{+}\right] \leq 0.15 \mathrm{M}, \mathrm{l}=0.2 \mathrm{~cm}, 25^{\circ} \mathrm{C}\right)$.

The stability and protonation constants of the $\mathrm{Ca}^{\mathrm{II}}-, \mathrm{Zn}^{\mathrm{II}}-, \mathrm{Cu}^{\mathrm{II}}-$ and $\mathrm{Gd}^{\mathrm{III}}-\mathrm{L} 2$ complexes are shown and compared with those of HPADO3A, HPDO3A, DOTA and BT-DO3A complexes in Table S1. The stability constants of the $\mathrm{Ca}^{\mathrm{II}}, \mathrm{Zn}^{\mathrm{II}}, \mathrm{Cu}^{\mathrm{II}}$ and $\mathrm{Gd}^{\mathrm{III}}$ complexes formed with L2, HPADO3A and BT-DO3A (Table S1) are very similar and about $1-5$ orders of magnitude lower than those of the corresponding DOTA and HPDO3A complexes, which might be explained by the lower $\log K_{1}{ }^{\mathrm{H}}$ and $\log K_{2}{ }^{\mathrm{H}}$ values of L2, HPADO3A and BT-DO3A ligands due to the formation of the Na ${ }^{\mathrm{I}}$-complexes. Although the stability constants obtained for $\mathrm{CuL} 2$ and $\mathrm{Cu}(\mathrm{HPADO} 3 \mathrm{~A})$ are significantly higher than that of $\mathrm{Cu}(\mathrm{BT}-\mathrm{DO} 3 \mathrm{~A})$ published earlier in literature, ${ }^{5}$ it can be assumed that $\mathrm{pH}$-potentiometric method used for the determination of the stability constant of $\mathrm{Cu}(\mathrm{BT}-\mathrm{DO} 3 \mathrm{~A})$ cannot provide reliable information for the estimation of the $\log K_{\mathrm{CuL}}$ value due to complete formation of $\mathrm{Cu}\left(\mathrm{H}_{2} \mathrm{~L}\right)$ species and the negligible amount of free $\mathrm{Cu}^{2+}$ ion at $\mathrm{pH}>1.7$.

The equilibrium constants characterizing the protonation of the carboxylate group in the 2hydroxypropanoic pendant arm of $\mathrm{ZnL} 2\left(\mathrm{ZnH}_{2} \mathrm{~L} 2\right), \mathrm{CuL} 2\left(\mathrm{CuH}_{2} \mathrm{~L} 2\right)$ and GdL2 (GdHL2) complexes are very similar to that of the free L2 ligand $\left(\log K_{4}{ }^{\mathrm{H}}\right)$, which indicate that the extra carboxylate group does not coordinate the metal ions. Interestingly, the stability constant of the diprotonated $\left.* \mathrm{Gd}_{(} \mathrm{H}_{2} \mathrm{~L} 2\right)$ intermediate $\left(\log K_{\mathrm{Gd}(\mathrm{H} 2 \mathrm{~L})}\right)$ is similar to that of ${ }^{*} \mathrm{Gd}\left(\mathrm{H}_{2} \mathrm{DOTA}\right)$ and about $1.5-2 \log K$ unit higher than that of $* \mathrm{Gd}\left(\mathrm{H}_{2} \mathrm{HPADO} 3 \mathrm{~A}\right)$ and ${ }^{*} \mathrm{Gd}\left(\mathrm{H}_{2} \mathrm{HPDO} 3 \mathrm{~A}\right)$, which might be interpreted by the coordination of the $\mathrm{Gd}^{\mathrm{III}}$ ion by the four carboxylate groups of L2 resulting in the formation of $* \mathrm{Gd}\left(\mathrm{H}_{2} \mathrm{~L} 1\right)$ intermediate similar to $* \mathrm{Gd}\left(\mathrm{H}_{2} \mathrm{DOTA}\right)$. 
Table S1. Protonation constants of L2, HPADO3A, HPDO3A, DOTA and BT-DO3A ligand, the stability and protonation constants of $\mathrm{Ca}^{\mathrm{II}}-, \mathrm{Zn}^{\mathrm{II}}-, \mathrm{Cu}^{\mathrm{II}}$ - and $\mathrm{Gd}^{\mathrm{III}}$-complexes at $25^{\circ} \mathrm{C}$

\begin{tabular}{|c|c|c|c|c|c|}
\hline & $\mathbf{L 2}$ & HPADO3A $^{\mathrm{a}}$ & HPDO3A $^{\mathrm{b}, \mathrm{c}}$ & DOTA $^{\mathbf{f}}$ & BT-DO3A $^{\mathrm{d}}$ \\
\hline \multirow{2}{*}{ I } & \multirow{2}{*}{$0.15 \mathrm{M}$} & \multirow{2}{*}{$\mathrm{NaCl}$} & $0.1 \mathrm{M}$ & $0.1 \mathrm{M}$ & $0.1 \mathrm{M}$ \\
\hline & & & $\mathrm{Me}_{4} \mathrm{NCl}$ & $\mathrm{NaCl}$ & $\mathrm{NaCl}$ \\
\hline $\log K_{1}{ }^{\mathrm{H}}$ & $8.95(3)$ & 8.96 & 11.96 & 9.37 & 9.46 \\
\hline $\log K_{2}{ }^{\mathrm{H}}$ & $8.95(2)$ & 9.07 & 9.43 & 9.14 & 9.36 \\
\hline $\log K_{3}{ }^{\mathrm{H}}$ & $4.22(3)$ & 4.22 & 4.30 & 4.63 & 4.17 \\
\hline $\log K_{4}{ }^{\mathrm{H}}$ & 3.74 (3) & 2.64 & 3.26 & 3.91 & 3.02 \\
\hline $\log K_{5}{ }^{\mathrm{H}}$ & $2.47(4)$ & 1.25 & - & - & - \\
\hline $\log K_{5}{ }^{\mathrm{H}}$ & $1.75(4)$ & - & - & - & - \\
\hline $\mathrm{CaL}$ & $11.63(1)$ & 12.13 & 14.83 & $16.37^{\mathrm{e}}$ & 12.1 \\
\hline $\mathrm{CaHL}$ & $5.20(5)$ & 4.67 & - & $3.60^{\mathrm{e}}$ & - \\
\hline $\mathrm{Ca}(\mathrm{L}) \mathrm{H}_{-1}$ & - & 11.50 & - & - & - \\
\hline ZnL & $17.81(6)$ & 17.18 & 19.37 & $18.7^{e}$ & 17.0 \\
\hline $\mathrm{ZnHL}$ & $3.86(5)$ & 3.67 & 3.7 & $5.33^{\mathrm{e}}$ & 4.3 \\
\hline $\mathrm{ZnH}_{2} \mathrm{~L}$ & $3.32(3)$ & 2.87 & - & $3.96^{\mathrm{e}}$ & - \\
\hline $\mathrm{ZnH}_{3} \mathrm{~L}$ & $2.29(5)$ & - & - & - & - \\
\hline $\mathrm{Zn}(\mathrm{L}) \mathrm{H}_{-1}$ & - & $10.79(5)$ & - & $10.62^{\mathrm{e}}$ & - \\
\hline${ }^{*} \mathrm{CuL}$ & $21.87(6)$ & 21.53 & 22.84 & $22.72^{\mathrm{e}}$ & 19.1 \\
\hline $\mathrm{CuHL}$ & $3.84(2)$ & 4.00 & 3.72 & $4.45^{\mathrm{e}}$ & 3.8 \\
\hline $\mathrm{CuH}_{2} \mathrm{~L}$ & $3.36(2)$ & 1.24 & 2.3 & $3.92^{\mathrm{e}}$ & 2.4 \\
\hline $\mathrm{CuH}_{3} \mathrm{~L}$ & $1.36(8)$ & - & - & - & - \\
\hline $\mathrm{Cu}(\mathrm{L}) \mathrm{H}_{-1}$ & - & 10.55 & - & - & - \\
\hline GdL & $19.26(3)$ & 18.41 & 23.8 & 24.7 & 18.7 \\
\hline GdHL & $3.36(3)$ & - & - & - & - \\
\hline${ }^{* *} \mathbf{G d H}_{2} \mathbf{L}$ & $6.73(3)$ & 5.72 & 5.10 & 6.07 & 4.53 \\
\hline $\mathbf{G d}(\mathbf{L}) \mathbf{H}_{-1}$ & $9.58(3)$ & 6.73 & $11.36^{d}$ & - & 9.48 \\
\hline
\end{tabular}

${ }^{\mathrm{a}}$ Ref. [11]; $0.1 \mathrm{M} \mathrm{KCl}, 25^{\circ} \mathrm{C}$; ${ }^{b}$ Ref. [13], $0.1 \mathrm{M} \mathrm{Me} 4 \mathrm{NCl}, 25^{\circ} \mathrm{C} ;{ }^{\mathrm{c}}$ Ref. [14]; ${ }^{\mathrm{d}}$ Ref. [5], $0.1 \mathrm{M} \mathrm{NaCl}$, $25^{\circ} \mathrm{C}$; ${ }^{\mathrm{e}}$ Ref. [15], $0.1 \mathrm{M} \mathrm{KCl}, 25^{\circ} \mathrm{C}$; ${ }^{\mathrm{f}}$ Ref. [16] $0.1 \mathrm{M} \mathrm{NaCl}, 25^{\circ} \mathrm{C}$; GdL1: $\log K_{\mathrm{Gd}(\mathrm{L}) \mathrm{H}-1}=9.36$ (6); *obtained by spectrophotometry; **stability constants of the protonated ${ }^{*} \mathrm{Gd}\left(\mathrm{H}_{2} \mathrm{~L}\right)$ out-of-cage complex (intermediate): $\mathrm{K}_{\mathrm{Gd}(\mathrm{H} 2 \mathrm{~L})}=\left[\mathrm{Gd}\left(\mathrm{H}_{2} \mathrm{~L}\right)\right] /\left[\mathrm{Gd}^{3+}\right]\left[\mathrm{H}_{2} \mathrm{~L}\right], 0.15 \mathrm{M} \mathrm{NaCl}, 25^{\circ} \mathrm{C}$

The protonation constant of the alkoxide- $\mathrm{O}^{-}$donor atom $\left(\log K_{\mathrm{Gd}(\mathrm{L}) \mathrm{H}-1)}\right)$ in $\mathrm{GdL} 1$ and GdL2 complexes are about 2 orders of magnitude lower than that of $\operatorname{Gd}(\mathrm{HPDO} 3 \mathrm{~A})$ due to the electron withdrawing effect of the carboxylate and ester pendants of the 2-hydroxypropanoic/ate side chain in GdL1 and GdL2. On the other hand, these values are about 3 orders of magnitude higher than that of 
Gd(HPADO3A) $\left(\log K_{\mathrm{Ga}(\mathrm{L}) \mathrm{H}-1}=6.73\right),{ }^{11}$ due to the significantly higher electron withdrawing effect of the amide functional group in the 2-hydroxypropanamide side chain of Gd(HPADO3A).

\section{Kinetic inertness of GdL2}

In order to investigate the kinetic inertness of GdL2, the dissociation reactions of GdL2 were followed by ${ }^{1} \mathrm{H}-\mathrm{NMR}$ relaxometry in the presence of large acid excess $([\mathrm{HCl}]=0.01-1.0 \mathrm{M})$ to guarantee the pseudo-first-order kinetic conditions. The $R_{1}{ }^{\text {obs }}$ values as a function of time for the dissociation reactions of GdL1 are shown in Figure S3.

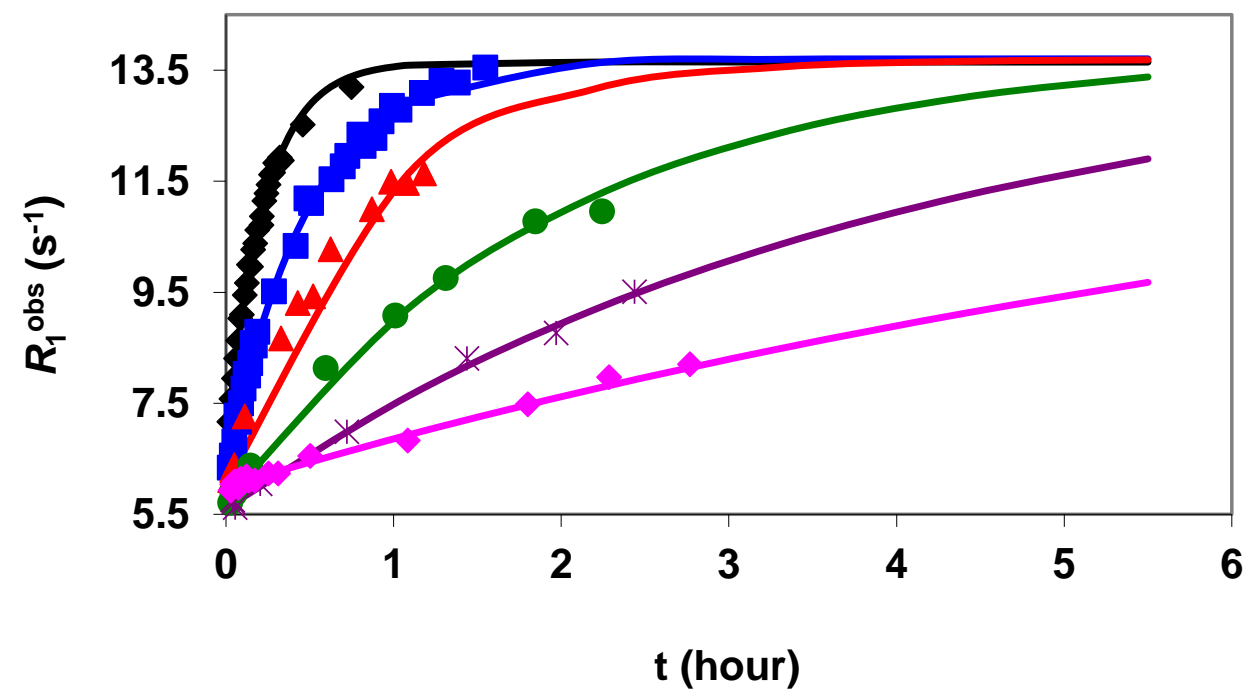

Figure S3. $r_{1 \mathrm{p}}$ values of GdL2 as a function of time in the presence of $\mathbf{0 . 7 0}(\diamond), \mathbf{0 . 2 9}(\square), \mathbf{0 . 1 6}(\mathbf{\Delta})$, $0.06(\bigcirc), 0.025(*)$ and $0.010(\diamond) \mathrm{M} \mathrm{HCl},\left([\mathrm{GdL} 2]=1.0 \mathrm{mM},\left[\mathrm{H}^{+}\right] \leq 0.15 \mathrm{M} \rightarrow\left[\mathrm{Na}^{+}\right]+\left[\mathrm{H}^{+}\right]=0.15 \mathrm{M}\right.$, $\left.25^{\circ} \mathrm{C}\right)$

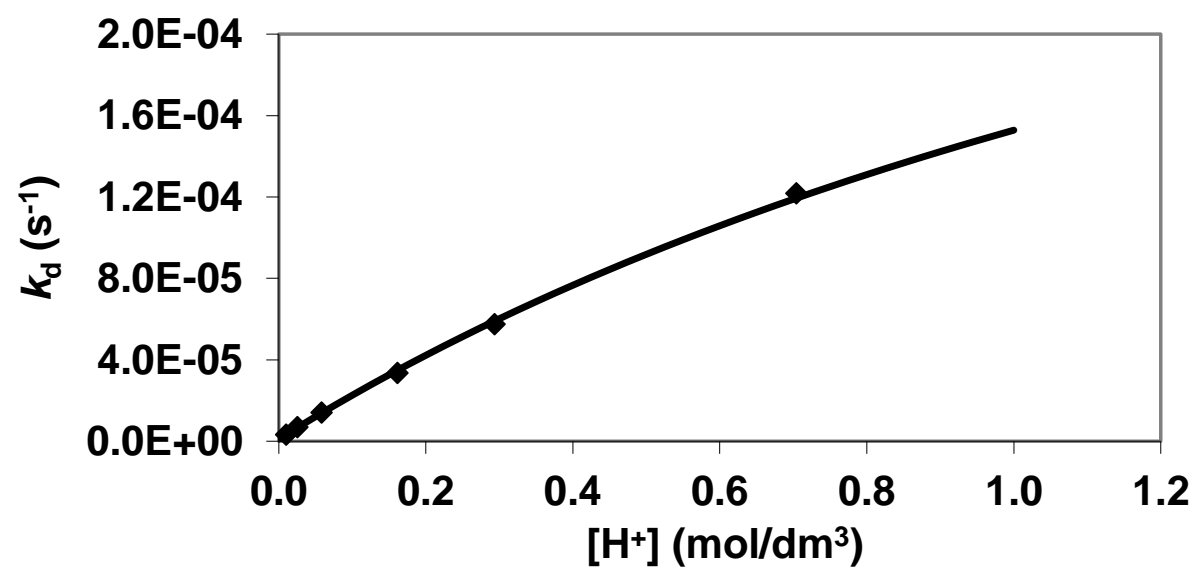

Figure S4. Pseudo-first-order rate constant $\left(k_{\mathrm{d}}\right)$ characterizing the dissociation of GdL2 as a function of $\left[\mathrm{H}^{+}\right]\left([\mathrm{GdL} 2]=1.0 \mathrm{mM},\left[\mathrm{H}^{+}\right] \leq 0.15 \mathrm{M} \rightarrow\left[\mathrm{Na}^{+}\right]+\left[\mathrm{H}^{+}\right]=0.15 \mathrm{M}, 25^{\circ} \mathrm{C}\right)$. 
In the presence of $\mathrm{HCl}$ excess, the dissociation of GdL2 can be treated as a pseudo-first-order process and the rate of the reaction can be expressed by Eq. (S7)

$$
-\frac{\mathrm{d}[\mathrm{GdL}]_{\mathrm{t}}}{\mathrm{dt}}=\mathrm{k}_{\mathrm{d}}[\mathrm{GdL}]_{\mathrm{tot}}
$$

where $k_{\mathrm{d}}$ is a pseudo-first-order rate constant, $[\mathrm{GdL}]_{\mathrm{t}}$ and $[\mathrm{GdL}]_{\mathrm{tot}}$ are the concentrations of the GdL species at time $t$ and the total concentration of the complex, respectively. The rates of the dissociation reactions were determined at different concentrations of $\mathrm{HCl}([\mathrm{HCl}]=0.01-1.0 \mathrm{M})$. The $k_{\mathrm{d}}$ values as a function of $\left[\mathrm{H}^{+}\right]$are shown in Figure $\mathrm{S} 4$.

As it is shown in Figure S4, $k_{\mathrm{d}}$ pseudo-first order rate constants increase with the concentration of $\mathrm{H}^{+}$, which can be explained by the proton assisted dissociation of GdL2. The proton assisted dissociation of GdL2 might occur by the equilibrium formation of a protonated ${ }^{*} \mathrm{Gd}\left(\mathrm{H}_{2} \mathrm{~L} 2\right)$ intermediate (Eq. (S8)), which dissociates spontaneously (Eq. (S9)).

$$
\begin{gathered}
\mathrm{Gd}(\mathrm{HL} 2)+\mathrm{H}^{+} \stackrel{K_{G d(H L)}^{H}}{\rightleftharpoons} \mathrm{Gd}\left(\mathrm{H}_{2} \mathrm{~L} 2\right) \\
K_{G d(H L)}^{H}=\frac{\left[\mathrm{Gd}\left(\mathrm{H}_{2} \mathrm{~L}\right)\right]}{[\mathrm{Gd}(\mathrm{HL})]\left[\mathrm{H}^{+}\right]} \\
*_{\mathrm{Gd}\left(\mathrm{H}_{2} \mathrm{~L} 2\right)} \stackrel{k_{\mathrm{GdH} 2 \mathrm{~L}}}{\longrightarrow} \mathrm{Gd}^{3+}+\mathrm{H}_{\mathrm{x}} \mathrm{L} 2
\end{gathered}
$$

$k_{\mathrm{GdH} 2 \mathrm{~L}}$ is the rate constant characterizing the dissociation of ${ }^{*} \mathrm{Gd}\left(\mathrm{H}_{2} \mathrm{~L} 2\right)$ intermediate. The $K^{\mathrm{H}}{ }_{\mathrm{GdHL}}$ is the protonation constant of the protonated Gd(HL2) species, which predominates at $\mathrm{pH}<3.0$ (Figure $\mathrm{S} 1)$. By considering the dissociation of the $* \mathrm{Gd}\left(\mathrm{H}_{2} \mathrm{~L} 2\right)$ intermediate (Eq. (S8)) and the rate of dissociation of GdL2 (Eq. (7)), the pseudo-first-order rate constant $\left(k_{\mathrm{d}}\right)$ can be expressed by Eq. (10).

$$
-\frac{d[G d L]}{d t}=k_{\mathrm{GdH}_{2} \mathrm{~L}}\left[\mathrm{Gd}\left(\mathrm{H}_{2} \mathrm{~L}\right)\right]
$$

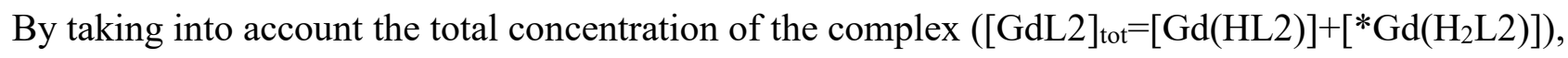
the protonation constants of $\operatorname{Gd}(\mathrm{HL} 2)\left(K^{\mathrm{H}} \mathrm{GdHL}\right.$, Eq. (8)) and Eq. (10), the pseudo-first-order rate constant $\left(k_{\mathrm{d}}\right)$ can be expressed as follows:

$$
k_{d}=\frac{k_{1}\left[H^{+}\right]}{1+K_{G d H L}^{H}\left[H^{+}\right]}
$$

where $k_{1}=k_{\mathrm{GdH} 2 \mathrm{~L}} \times K^{\mathrm{H}} \mathrm{GdHL}$ are the rate constants characterizing the proton assisted dissociation of Gd(HL2). $k_{1}$ value of Gd(HL2) were calculated by fitting of the kinetic data (Figure S12) to Eq. (S11). 


\section{X-ray diffraction studies of $\left[\mathrm{Gd}\left(\mathrm{L} 2^{2}\right) \mathrm{H}_{-1}\left(\mathrm{OH}^{-}\right)\right]^{3-}$ complex}

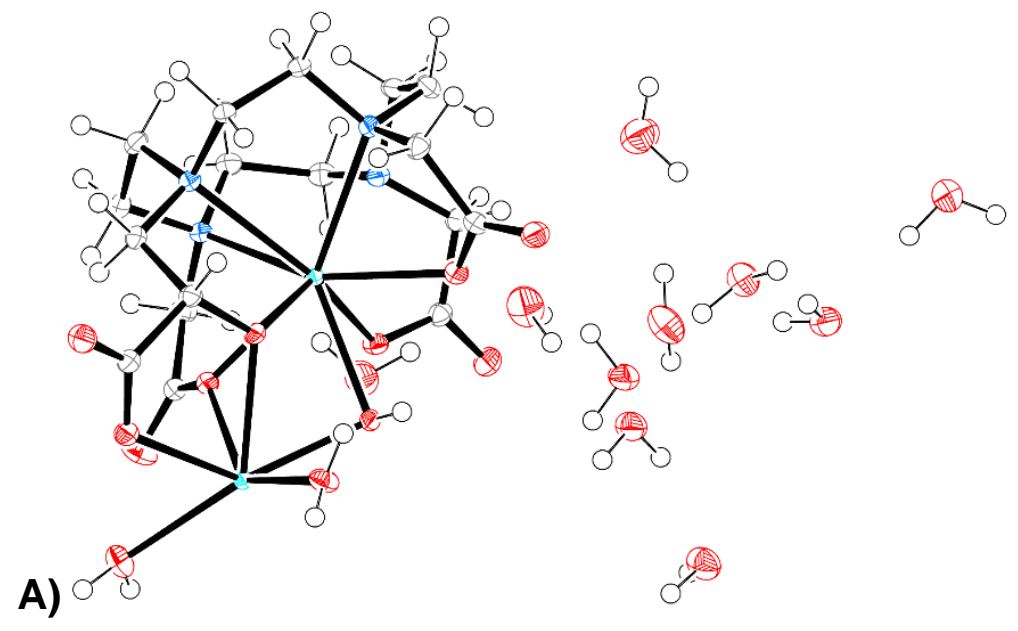

B)

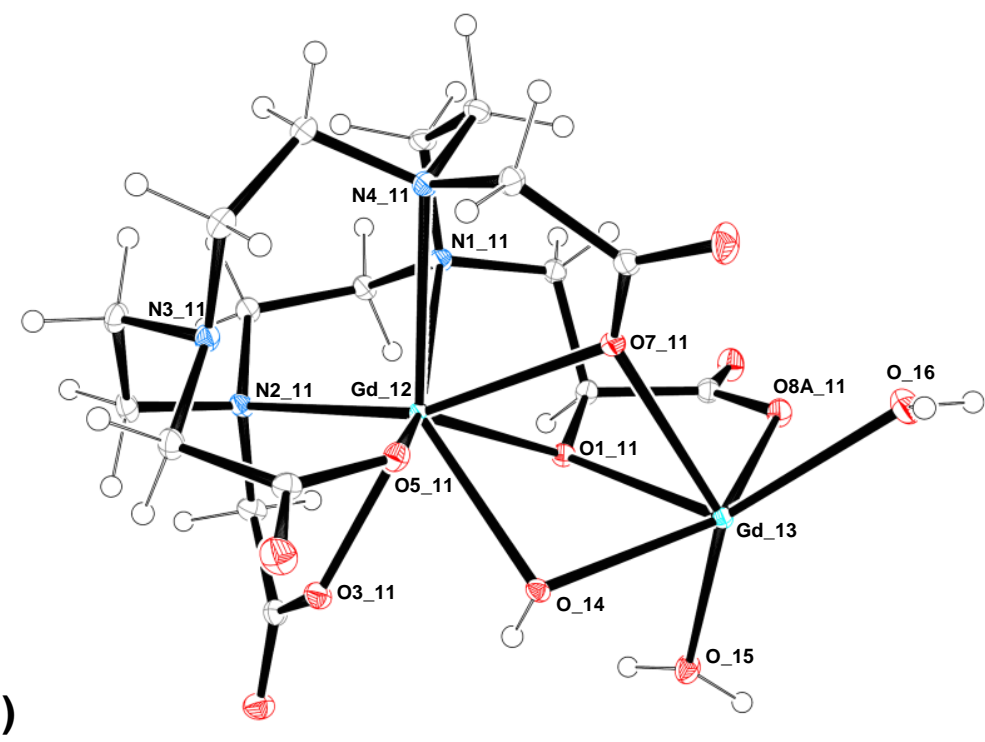

Figure S5. Ellipsoids representation of crystallographic asymmetric unit content (ASU) for dimeric $\left[\mathrm{Gd}(\mathrm{L} 2) \mathrm{H}_{-1}\left(\mathrm{OH}^{-}\right)\right]^{3-}(50 \%$ probability): A) complete ASU content; B) solvent water molecules omitted for clarity. Naming scheme used for $\mathrm{Gd}^{\mathrm{III}}$-ion coordination spheres is reported. 

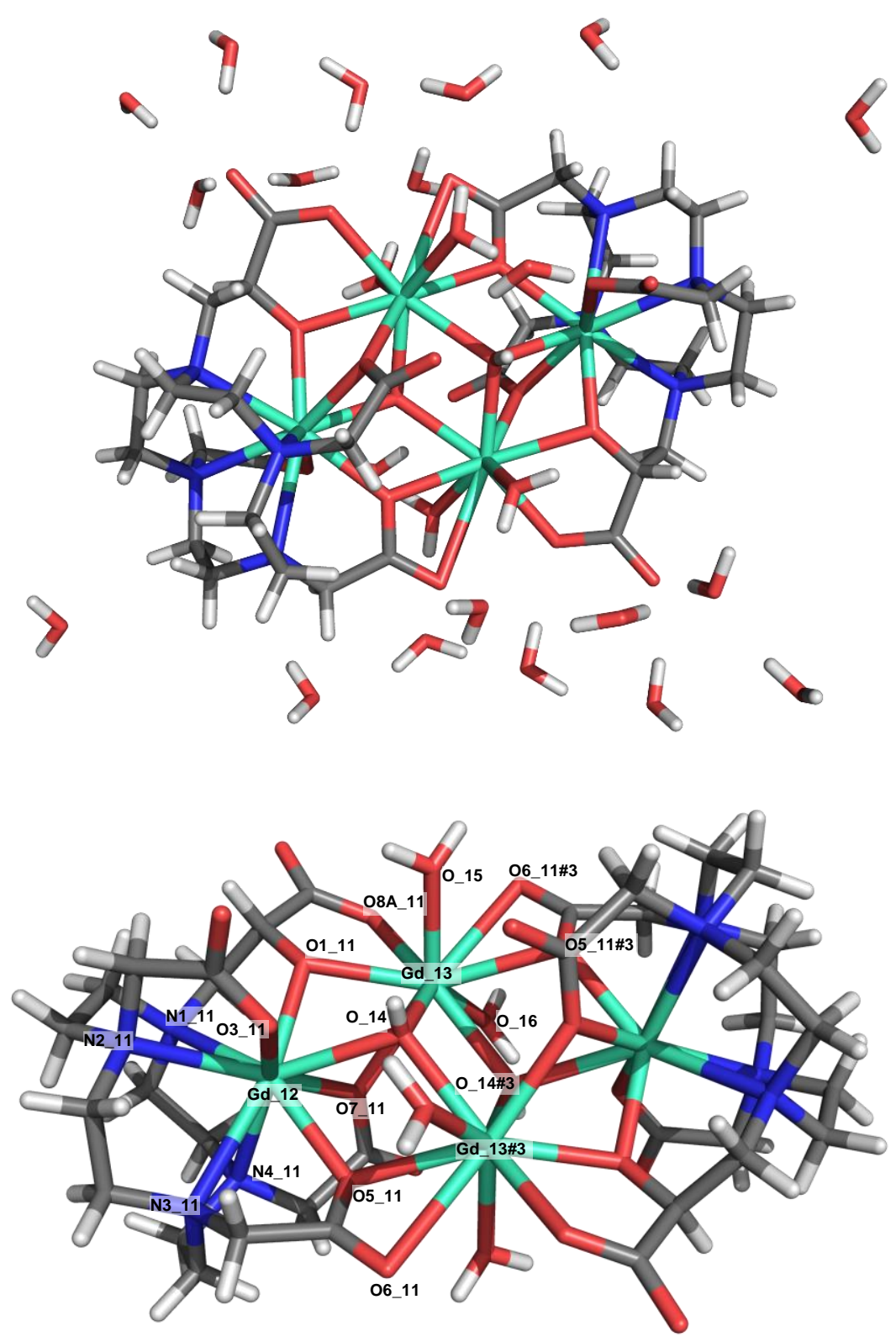

Figure S6. Sticks representation of dimeric $\left[\mathrm{Gd}(\mathrm{L} 2) \mathrm{H}_{-1}\left(\mathrm{OH}^{-}\right)\right]^{3-}$. Hydrogen bonded water molecules surrounds the capsule (omitted for clarity). Naming scheme used for Gadolinium coordination spheres is reported. A crystallographic inversion center lies on dimeric $\left[\mathrm{Gd}(\mathrm{L} 2) \mathrm{H}_{-1}\left(\mathrm{OH}^{-}\right)\right]^{3-}$ barycenter. 


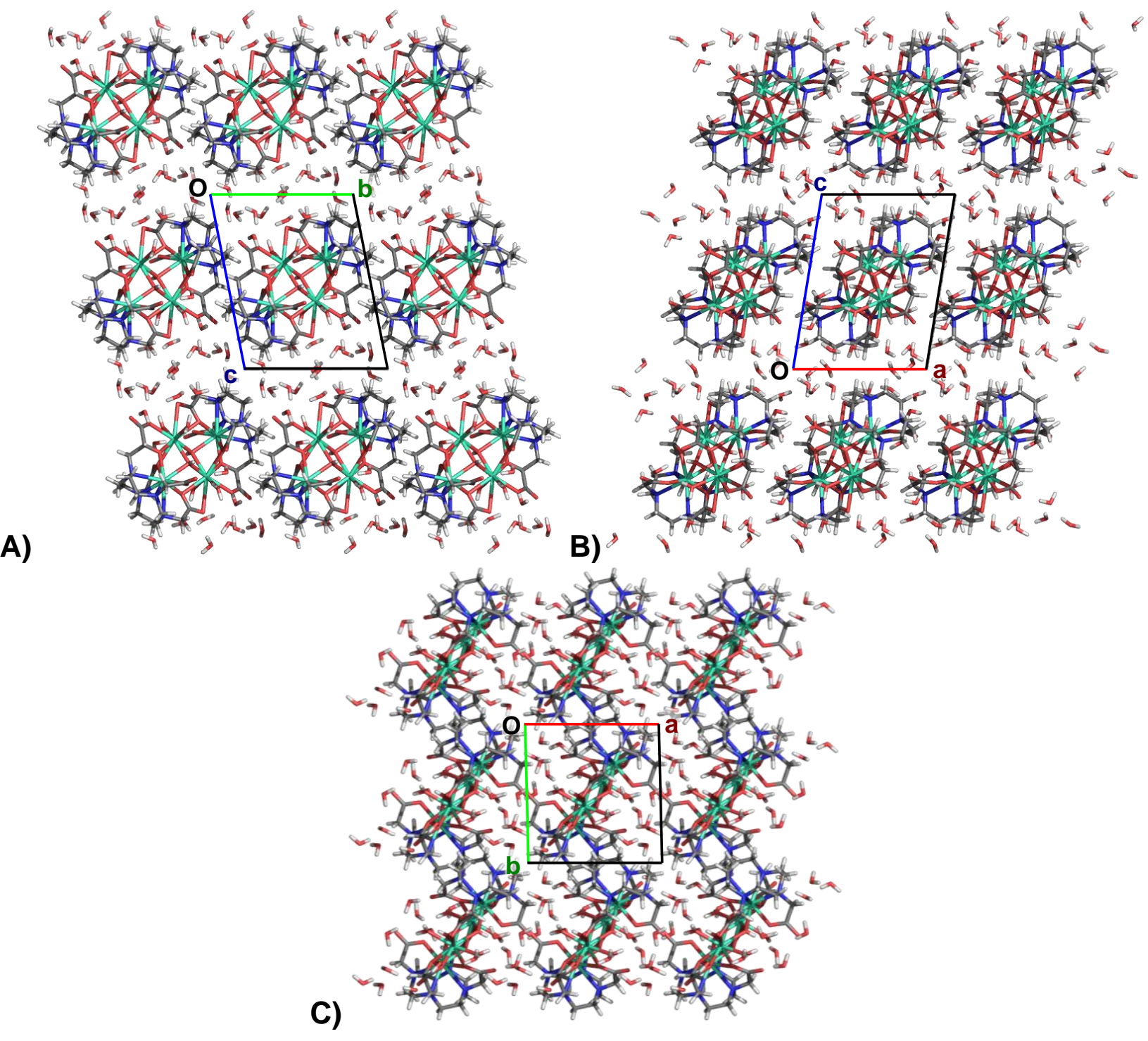

Figure S7. Crystal packing of dimeric $\left[\mathrm{Gd}(\mathrm{L} 2) \mathrm{H}_{-1}\left(\mathrm{OH}^{-}\right)\right]^{3-}$ along crystallographic $a, b$ and $c$ axis. 
Table S2. Crystallographic data and refinement details for dimeric $\left[\mathrm{Gd}(\mathrm{L} 2) \mathrm{H}_{-1}\left(\mathrm{OH}^{-}\right)\right]^{3-}$.

\author{
Volume $\left(\AA^{3}\right)$ \\ $\mathrm{Z}$ \\ Density (calculated) $\left(\mathrm{g} \cdot \mathrm{cm}^{-3}\right)$ \\ Absorption coefficient $\left(\mathrm{mm}^{-1}\right)$ \\ $\mathrm{F}(000)$ \\ Crystal size $\left(\mathrm{mm}^{3}\right)$ \\ Crystal habit \\ Theta range for data collection \\ Resolution ( $\mathrm{A})$ \\ Index ranges
}

Reflections collected

Independent reflections (data with $\mathrm{I}>2 \sigma(\mathrm{I})$ )

Data multiplicity (max resltn)

$\mathrm{I} / \sigma(\mathrm{I})$ (max resltn)

$\mathrm{R}_{\text {merge }}$ (max resltn)

Data completeness (max resltn)

Refinement method

Data / restraints / parameters

Goodness-of-fit on $\mathrm{F}^{2}$

$\Delta / \sigma_{\max }$

Final R indices $[\mathrm{I}>2 \sigma(\mathrm{I})]^{a}$

$\mathrm{R}$ indices (all data) ${ }^{a}$

Largest diff. peak and hole $\left(\mathrm{e} \cdot \AA^{-3}\right)$

R.M.S.D. from mean $\left(\mathrm{e} \cdot \AA^{-3}\right)$
$\left[\mathrm{Gd}_{4}\left(\mathrm{C}_{17} \mathrm{H}_{25} \mathrm{~N}_{4} \mathrm{O}_{9}\right)_{2}(\mathrm{OH})_{2}\left(\mathrm{H}_{2} \mathrm{O}\right)_{4} \cdot 20 \mathrm{H}_{2} \mathrm{O}\right]$ 2087813

$\mathrm{C}_{34} \mathrm{H}_{100} \mathrm{Gd}_{4} \mathrm{~N}_{8} \mathrm{O}_{44}$

1954.21

$100(2)$

0.700

Triclinic

$P-1$

$a=10.541(2) \AA$

$b=11.172(2) \AA$

$c=14.209(3) \AA$

$\alpha=78.78(3)^{\circ}$

$\beta=80.23(3)^{\circ}$

$\gamma=86.89(3)^{\circ}$

1617.1(6)

1

2.007

3.979

968

$0.12 \times 0.08 \times 0.05$

Colorless rods

$2.11^{\circ}$ to $30.00^{\circ}$

0.70

$-14 \leq \mathrm{h} \leq 13$

$-15 \leq \mathrm{k} \leq 15$

$-20 \leq 1 \leq 20$

49466

9571 (9542)

$5.02(4.38)$

$27.64(25.43)$

$0.0485(0.0502)$

$97.2 \%(93.6 \%)$

Full-matrix least-squares on $\mathrm{F}^{2}$

9571 / 37 / 485

1.063

0.002

$\mathrm{R}_{1}=0.0207, \mathrm{wR}_{2}=0.0540$

$\mathrm{R}_{1}=0.0207, \mathrm{wR}_{2}=0.0542$

0.898 and -1.654

0.126

${ }^{a} \mathrm{R}_{1}=\Sigma\left\|_{F \mathrm{O}}|-| F \mathrm{c}\right\| / \Sigma\left|F_{\mathrm{O}}\right|, \mathrm{wR}_{2}=\left\{\Sigma\left[w\left(F_{\mathrm{O}}^{2}-F_{\mathrm{c}^{2}}\right)^{2}\right] / \Sigma\left[w\left(F \mathrm{O}^{2}\right)^{2}\right]\right\}^{1 / 2}$ 
Table S3. Selected bond distances and angles ( $\AA$ and degrees) for coordination spheres of the crystallographically independent $\mathrm{Gd}^{\mathrm{III}}$ centers in dimeric $\left[\mathrm{Gd}(\mathrm{L} 2) \mathrm{H}_{-1}\left(\mathrm{OH}^{-}\right)\right]^{3-}$. $\left(\mathrm{Gd}_{-} 12\right.$ and $\left.\mathrm{Gd}_{-} 13\right)$. Naming scheme is reported in Figure S6.

\begin{tabular}{|c|c|c|c|c|c|c|c|}
\hline \multicolumn{8}{|c|}{ Gd_12 - diGdHPDO4A } \\
\hline Distances & (̊) & Angles & $\left({ }^{\circ}\right)$ & Angles & $\left({ }^{\circ}\right)$ & Angles & $\left({ }^{\circ}\right)$ \\
\hline Gd_12-O1_11 & $2.289(2)$ & O3_11-Gd_12-O1_11 & $94.35(6)$ & N1_11-Gd_12-O7_11 & $88.11(5)$ & O5_11-Gd_12-O3_11 & $86.61(6)$ \\
\hline Gd_12-O3_11 & $2.406(2)$ & O5_11-Gd_12-O1_11 & $130.73(5)$ & N2_11-Gd_12-O7_11 & $155.19(5)$ & O7_11-Gd_12-O3_11 & $138.50(5)$ \\
\hline Gd_12-O5_11 & $2.357(2)$ & O7_11-Gd_12-O1_11 & $69.69(5)$ & N3_11-Gd_12-O7_11 & $117.83(5)$ & N1_11-Gd_12-O3_11 & $121.98(5)$ \\
\hline Gd_12-O7_11 & $2.444(2)$ & N1_11-Gd_12-O1_11 & $67.72(6)$ & N4_11-Gd_12-O7_11 & $63.29(5)$ & N2_11-Gd_12-O3_11 & $63.55(5)$ \\
\hline Gd_12-N1_11 & $2.659(2)$ & N2_11-Gd_12-O1_11 & $102.20(6)$ & O_14-Gd_12-O7_11 & $70.69(5)$ & N3_11-Gd_12-O3_11 & $85.83(6)$ \\
\hline Gd_12-N2_11 & $2.662(2)$ & N3_11-Gd_12-O1_11 & $167.47(5)$ & Gd_13-Gd_12-O7_11 & $43.04(4)$ & N4_11-Gd_12-O3_11 & $150.67(5)$ \\
\hline Gd_12-N3_11 & $2.749(2)$ & N4_11-Gd_12-O1_11 & $114.22(6)$ & Gd_13\#1-Gd_12-O7_11 & $68.76(4)$ & O_14-Gd_12-O3_11 & $67.81(5)$ \\
\hline Gd_12-N4_11 & $2.703(2)$ & O_14-Gd_12-O1_11 & $67.88(5)$ & N3_11-Gd_12-N2_11 & $66.67(6)$ & Gd_13-Gd_12-O3_11 & $100.28(4)$ \\
\hline Gd_12-O_14 & $2.461(1)$ & Gd_13-Gd_12-O1_11 & $40.37(4)$ & N4_11-Gd_12-N2_11 & $102.02(5)$ & Gd_13\#1-Gd_12-O3_11 & $76.71(4)$ \\
\hline Gd_12-Gd_13 & $3.621(1)$ & Gd_13\#1-Gd_12-O1_11 & $98.75(4)$ & O_14-Gd_12-N2_11 & $129.36(5)$ & O7_11-Gd_12-O5_11 & $77.43(5)$ \\
\hline \multirow[t]{9}{*}{ Gd_12-Gd_13\#1 } & $4.060(1)$ & N2_11-Gd_12-N1_11 & $67.33(5)$ & Gd_13-Gd_12-N2_11 & $140.49(4)$ & N1_11-Gd_12-O5_11 & $147.25(5)$ \\
\hline & & N3_11-Gd_12-N1_11 & $101.59(6)$ & Gd_13\#1-Gd_12-N2_11 & $135.99(4)$ & N2_11-Gd_12-O5_11 & $121.52(5)$ \\
\hline & & N4_11-Gd_12-N1_11 & $67.46(5)$ & O_14-Gd_12-N3_11 & $123.28(5)$ & N3_11-Gd_12-O5_11 & $61.80(5)$ \\
\hline & & O_14-Gd_12-N1_11 & $135.10(5)$ & O_14-Gd_12-N4_11 & $127.84(5)$ & N4_11-Gd_12-O5_11 & $79.80(5)$ \\
\hline & & Gd_13-Gd_12-N1_11 & $98.33(4)$ & Gd_13-Gd_12-N4_11 & $105.77(4)$ & O_14-Gd_12-O5_11 & $67.13(5)$ \\
\hline & & Gd_13\#1-Gd_12-N1_11 & $156.44(4)$ & Gd_13\#1-Gd_12-N4_11 & $103.90(4)$ & Gd_13-Gd_12-O5_11 & $90.92(4)$ \\
\hline & & N4_11-Gd_12-N3_11 & $64.83(5)$ & Gd_13-Gd_12-O_14 & $39.91(4)$ & Gd_13\#1-Gd_12-O5_11 & $33.73(4)$ \\
\hline & & Gd_13-Gd_12-N3_11 & $151.83(4)$ & Gd_13\#1-Gd_12-O_14 & $33.51(4)$ & & \\
\hline & & Gd_13\#1-Gd_12-N3_11 & $93.49(4)$ & & & Gd_13\#1-Gd_12-Gd_13 & $61.90(1)$ \\
\hline
\end{tabular}

\begin{tabular}{|c|c|c|c|c|c|c|c|}
\hline \multicolumn{8}{|c|}{ Gd_13 - diGdHPDO4A } \\
\hline Distances & $(\stackrel{\AA}{\mathbf{A}})$ & Angles & $\left({ }^{\circ}\right)$ & Angles & $\left({ }^{\circ}\right)$ & Angles & $\left({ }^{\circ}\right)$ \\
\hline Gd_13-O1_11 & $2.392(2)$ & O5_11\#3-Gd_13-O1_11 & $146.82(5)$ & O_14-Gd_13-O8A_11 & $135.77(5)$ & O7_11-Gd_13-O6_11\#3 & $144.70(5)$ \\
\hline Gd_13-O5_11\#3 & $2.475(2)$ & O6_11\#3-Gd_13-O1_11 & $124.75(5)$ & O_15-Gd_13-O8A_11 & $85.25(6)$ & O8A_11-Gd_13-O6_11\#3 & $66.89(5)$ \\
\hline Gd_13-O6_11\#3 & $2.828(2)$ & O7_11-Gd_13-O1_11 & $67.47(5)$ & O_16-Gd_13-O8A_11 & $76.35(5)$ & O_14-Gd_13-O6_11\#3 & $142.17(5)$ \\
\hline Gd_13-O7_11 & $2.480(2)$ & O8A_11-Gd_13-O1_11 & $67.74(5)$ & O_14\#3-Gd_13-O8A_11 & 151.13(5) & O_15-Gd_13-O6_11\#3 & $71.27(5)$ \\
\hline Gd_13-O8A_11 & $2.409(2)$ & O_14-Gd_13-O1_11 & $68.19(5)$ & Gd_12-Gd_13-O8A_11 & 99.92(4) & O_16-Gd_13-O6_11\#3 & $63.96(5)$ \\
\hline Gd_13-O_14 & $2.344(2)$ & O_15-Gd_13-O1_11 & $75.22(5)$ & Gd_13\#1-Gd_13-O8A_11 & $163.40(4)$ & O_14\#3-Gd_13-O6_11\#3 & 106.13(5) \\
\hline Gd_13-O_15 & $2.386(2)$ & O_16-Gd_13-O1_11 & $130.47(5)$ & O_15-Gd_13-O_14 & $80.25(6)$ & Gd_12-Gd_13-O6_11\#3 & $162.99(3)$ \\
\hline Gd_13-O_16 & $2.470(2)$ & O_14\#3-Gd_13-O1_11 & $128.65(5)$ & O_16-Gd_13-O_14 & $139.32(6)$ & Gd_13\#1-Gd_13-O6_11\#3 & $129.52(3)$ \\
\hline Gd_13-O_14\#3 & $2.425(2)$ & Gd_12-Gd_13-O1_11 & $38.29(4)$ & O_14\#3-Gd_13-O_14 & $67.38(6)$ & O8A_11-Gd_13-O7_11 & $94.45(5)$ \\
\hline Gd_13-Gd_12 & $3.621(1)$ & Gd_13\#1-Gd_13-O1_11 & 99.33(4) & Gd_12-Gd_13-O_14 & $42.33(3)$ & O_14-Gd_13-O7_11 & $71.99(5)$ \\
\hline \multirow[t]{9}{*}{ Gd_13-Gd_13\#1 } & $3.968(1)$ & O6_11\#3-Gd_13-O5_11\#3 & $48.39(5)$ & Gd_13\#1-Gd_13-O_14 & $34.33(4)$ & O_15-Gd_13-O7_11 & $139.54(5)$ \\
\hline & & O7_11-Gd_13-O5_11\#3 & $140.31(5)$ & O_16-Gd_13-O_15 & $135.20(5)$ & O_16-Gd_13-O7_11 & $83.07(6)$ \\
\hline & & O8A_11-Gd_13-O5_11\#3 & $115.14(5)$ & O_14\#3-Gd_13-O_15 & 120.11(5) & O_14\#3-Gd_13-O7_11 & $75.39(5)$ \\
\hline & & O_14-Gd_13-O5_11\#3 & $99.76(5)$ & Gd_12-Gd_13-O_15 & 97.82(4) & Gd_12-Gd_13-O7_11 & $42.26(3)$ \\
\hline & & O_15-Gd_13-O5_11\#3 & $72.24(5)$ & Gd_13\#1-Gd_13-O_15 & 101.92(5) & Gd_13\#1-Gd_13-O7_11 & $70.32(3)$ \\
\hline & & O_16-Gd_13-O5_11\#3 & $79.27(5)$ & O_14\#3-Gd_13-O_16 & $75.63(5)$ & Gd_12-Gd_13-O_14\#3 & $90.58(4)$ \\
\hline & & O_14\#3-Gd_13-O5_11\#3 & $65.92(5)$ & Gd_12-Gd_13-O_16 & $125.19(5)$ & Gd_13\#1-Gd_13-O_14\#3 & $33.05(4)$ \\
\hline & & Gd_12-Gd_13-O5_11\#3 & $142.01(4)$ & Gd_13\#1-Gd_13-O_16 & 107.24(5) & & \\
\hline & & Gd_13\#1-Gd_13-O5_11\#3 & $81.42(4)$ & & & Gd_12-Gd_13-Gd_13\#1 & $64.49(1)$ \\
\hline
\end{tabular}


Table S4. Geometrical parameters of polar contacts found in dimeric $\left[\mathrm{Gd}(\mathrm{L} 2) \mathrm{H}_{-1}\left(\mathrm{OH}^{-}\right)\right]^{3-}$ crystal packing. Naming scheme is reported in Figure S8.

\begin{tabular}{|c|c|c|c|c|}
\hline \multicolumn{5}{|c|}{ diGdHPDO4A } \\
\hline D-H $\cdots A$ & d(D-H) $(\AA)$ & $\mathbf{d}(\mathbf{H} \cdots \mathbf{A})(\stackrel{\AA}{)})$ & $\mathbf{d}(\mathbf{D} \cdots \mathbf{A})(\AA)$ & $<($ DHA $)\left({ }^{\circ}\right)$ \\
\hline O_14-H1_14...O3_11 & $0.73(3)$ & $2.35(3)$ & $2.715(2)$ & $113(3)$ \\
\hline O_15-H1_15...O_24\#1 & $0.869(5)$ & $1.912(7)$ & $2.778(2)$ & $174(3)$ \\
\hline O_15-H2_15...O4_11\#2 & $0.869(5)$ & $1.875(9)$ & $2.729(2)$ & $167(3)$ \\
\hline O_16-H1_16...O26\#1 & $0.871(5)$ & $2.009(7)$ & $2.877(3)$ & $174(4)$ \\
\hline O_16-H2_16...O3_11\#1 & $0.869(5)$ & $2.29(4)$ & $3.008(2)$ & $141(5)$ \\
\hline O_16-H2_16...O_25\#1 & $0.869(5)$ & $2.52(4)$ & $3.137(3)$ & $129(5)$ \\
\hline $\mathrm{C} 11$ _11-H11A_11...O_25\#2 & 0.99 & 2.59 & $3.553(3)$ & 164.1 \\
\hline C10_11-H10A_11...O_29\#3 & 0.99 & 2.54 & $3.521(3)$ & 171.4 \\
\hline C13_11-H13A_11...O_23 & 0.99 & 2.50 & $3.435(3)$ & 156.9 \\
\hline C14_11-H14A_11...O_29\#3 & 0.99 & 2.53 & $3.509(3)$ & 170.5 \\
\hline C18_11-H18A_11...O_29\#3 & 0.99 & 2.62 & $3.597(3)$ & 169.4 \\
\hline C21_11-H21B_11...O8 A_11\#4 & 0.99 & 2.63 & $3.531(3)$ & 150.7 \\
\hline C22_11-H22A_11...O_29\#3 & 0.99 & 2.62 & $3.602(3)$ & 172.0 \\
\hline C2_11-H2_11...O_25\#2 & 1.00 & 2.40 & $3.377(3)$ & 164.6 \\
\hline O_21-H1_21...O4A_11\#2 & 0.87 & $1.893(6)$ & $2.762(3)$ & $177(3)$ \\
\hline O_21-H2_21...O_25 & 0.87 & $1.859(9)$ & $2.708(3)$ & $165(3)$ \\
\hline O_22-H1_22...O8A_11\#1 & 0.87 & $1.949(6)$ & $2.822(2)$ & 179(3) \\
\hline O_22-H2_22...O_28 & 0.87 & $2.035(12)$ & $2.863(3)$ & $158(3)$ \\
\hline O_23-H1_23...O_24\#5 & 0.87 & $1.941(17)$ & $2.773(3)$ & $158(4)$ \\
\hline O_23-H2_23...O_21 & 0.87 & $2.020(11)$ & $2.869(3)$ & $163(3)$ \\
\hline O_24-H1_24...O_30\#6 & 0.87 & $1.945(16)$ & $2.769(3)$ & $158(4)$ \\
\hline O_24-H2_24...O_27 & 0.87 & $1.962(9)$ & $2.821(3)$ & $169(4)$ \\
\hline O_25-H1_25...O4_11 & 0.87 & $1.807(6)$ & $2.676(2)$ & $172(2)$ \\
\hline O_25-H2_25...O8_11\#1 & 0.87 & $1.865(13)$ & $2.709(2)$ & $162(4)$ \\
\hline O_26-H1_26...O_27\#6 & 0.87 & $2.049(19)$ & $2.809(3)$ & $145(3)$ \\
\hline O_26-H2_26...O_22 & 0.87 & $1.971(18)$ & $2.785(3)$ & $155(4)$ \\
\hline O_27-H1_27...O_23\#6 & 0.87 & $1.843(7)$ & $2.705(3)$ & $170(3)$ \\
\hline O_27-H2_27...O_6_11 & 0.87 & $2.43(3)$ & $2.917(3)$ & $116(3)$ \\
\hline $\mathrm{O} \_27-\mathrm{H} 2 \_27 . . \mathrm{O} \_22$ & 0.87 & $1.988(11)$ & $2.839(3)$ & $165(3)$ \\
\hline O_28-H1_28...O4A_11\#1 & 0.87 & $1.877(11)$ & $2.730(2)$ & $166(4)$ \\
\hline O_28-H2_28...O_30\#7 & 0.87 & $1.986(8)$ & $2.843(3)$ & $168(3)$ \\
\hline O_29-H1_29...O_26 & 0.87 & $1.899(14)$ & $2.718(3)$ & $156(3)$ \\
\hline O_29-H2_29...O_21 & 0.87 & $1.875(10)$ & $2.726(3)$ & $165(3)$ \\
\hline O_30-H1_30...O_28\#8 & 0.87 & $1.931(11)$ & $2.783(3)$ & $166(4)$ \\
\hline O_30-H2_30...O_29 & 0.87 & $1.887(7)$ & $2.752(3)$ & $172(4)$ \\
\hline
\end{tabular}

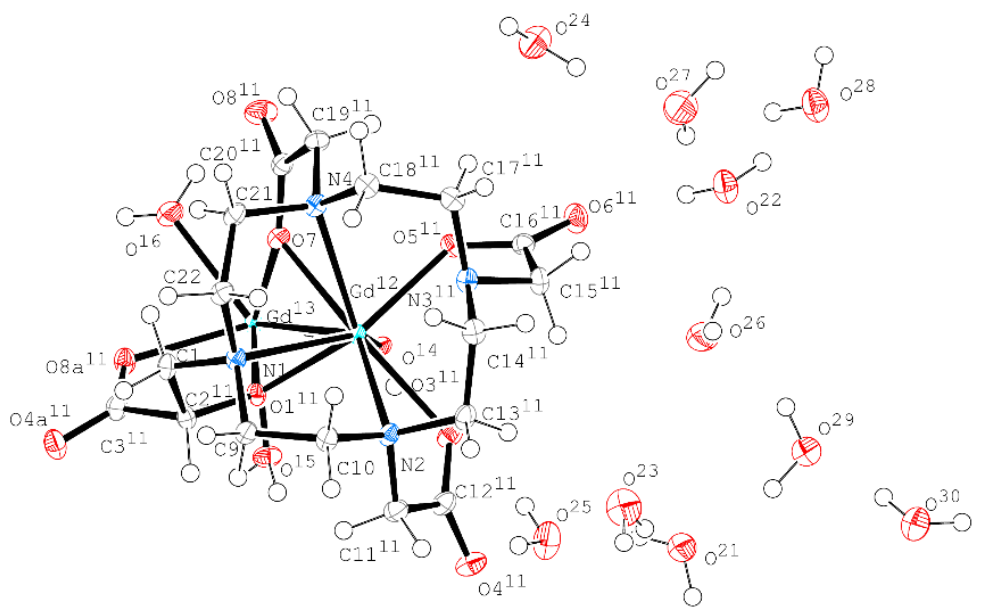

Figure S8. Naming scheme for the geometrical parameters of polar contacts found in dimeric $\left[\mathrm{Gd}(\mathrm{L} 2) \mathrm{H}_{-1}\left(\mathrm{OH}^{-}\right)\right]^{3-}$ crystal packing. 
4. ${ }^{1} \mathrm{H}$ and ${ }^{13} \mathrm{C}$ NMR spectra of protected and deprotected ligands

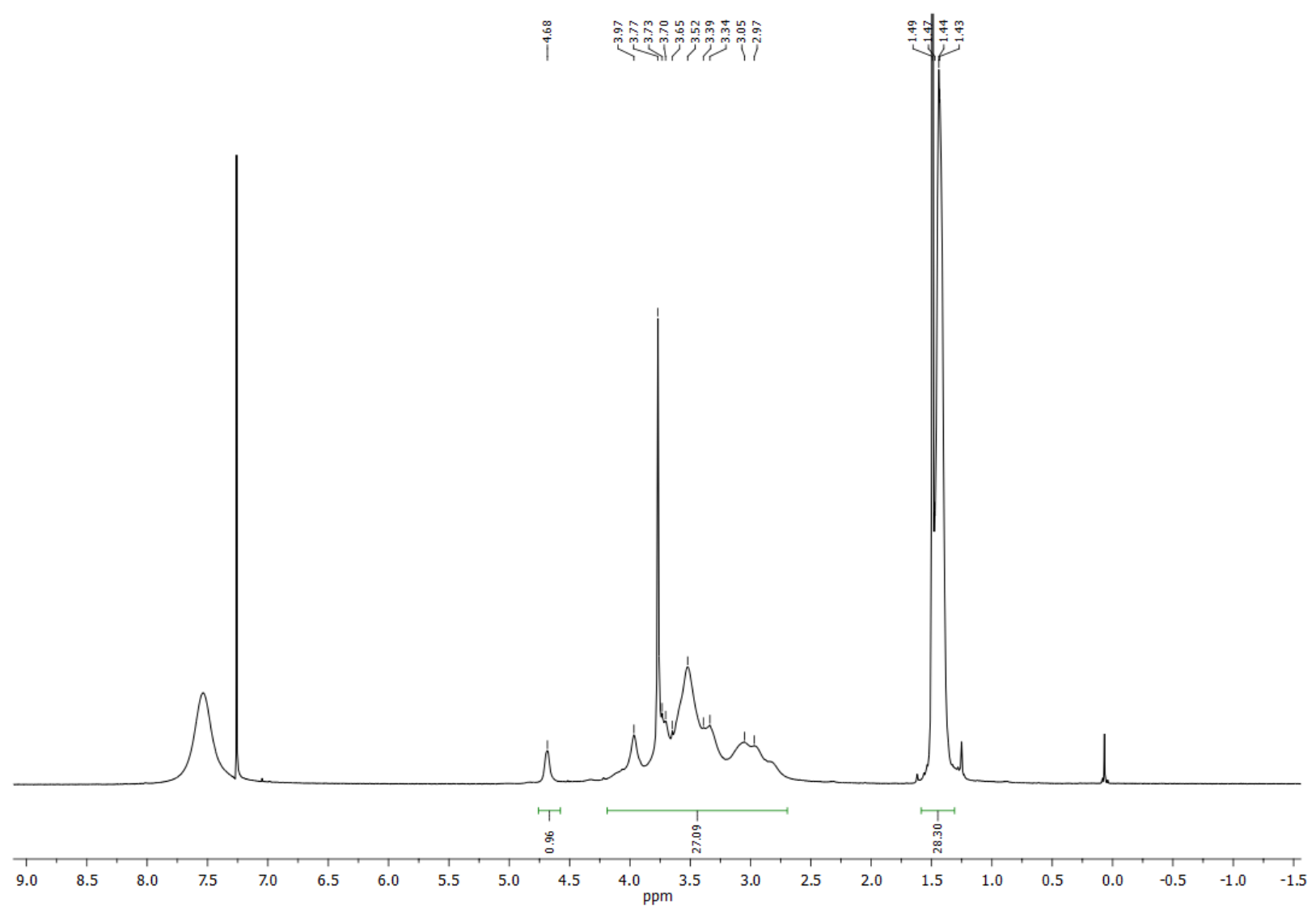

Fig. S9a ${ }^{1} \mathrm{H}$ NMR spectrum of $\mathbf{L} \mathbf{1}(\mathbf{O} t \mathbf{B u})_{3}$

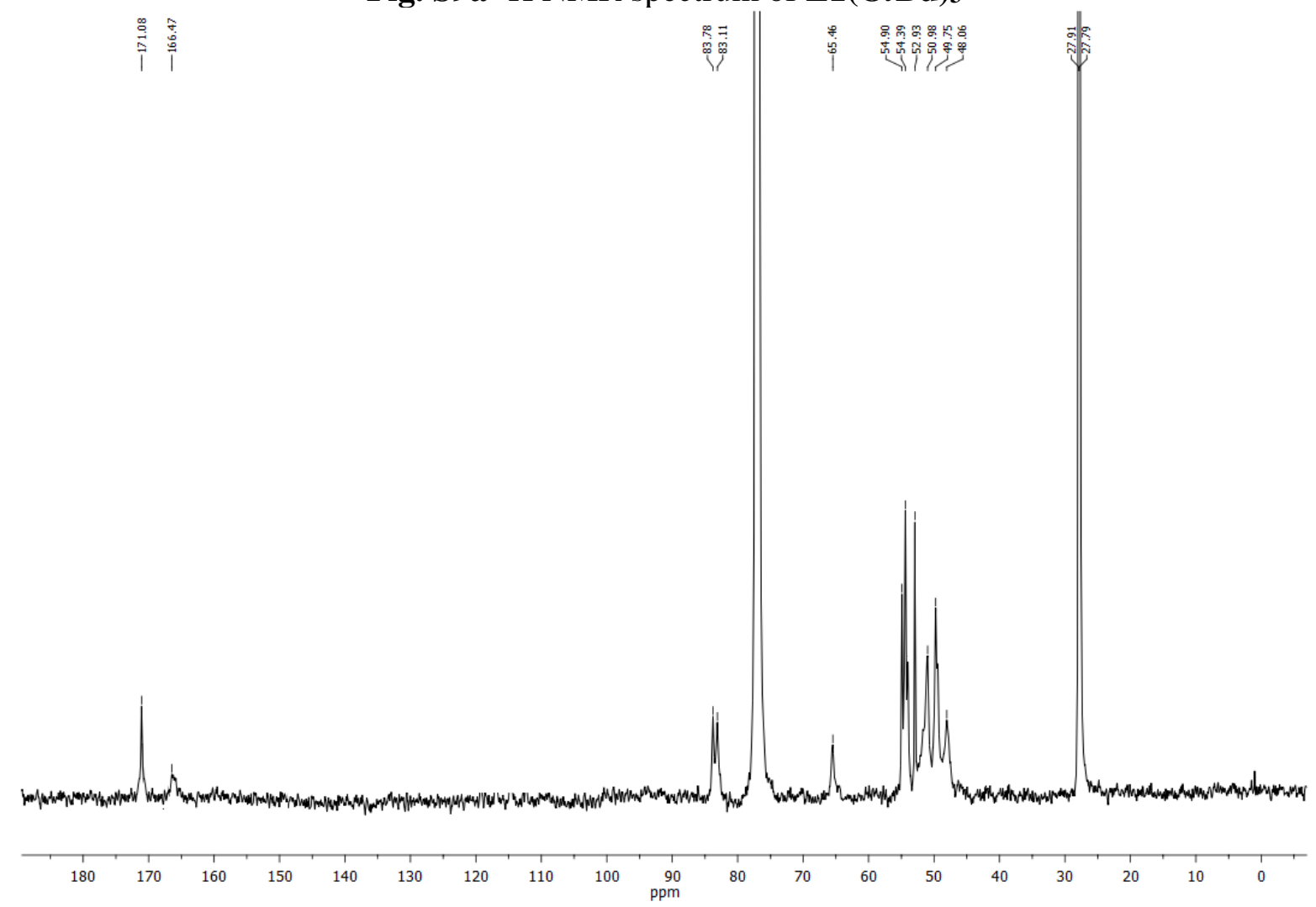


Fig. S9b ${ }^{13} \mathrm{C}$ NMR spectrum of $\mathbf{L 1}(\mathbf{O} t \mathbf{B u})_{3}$

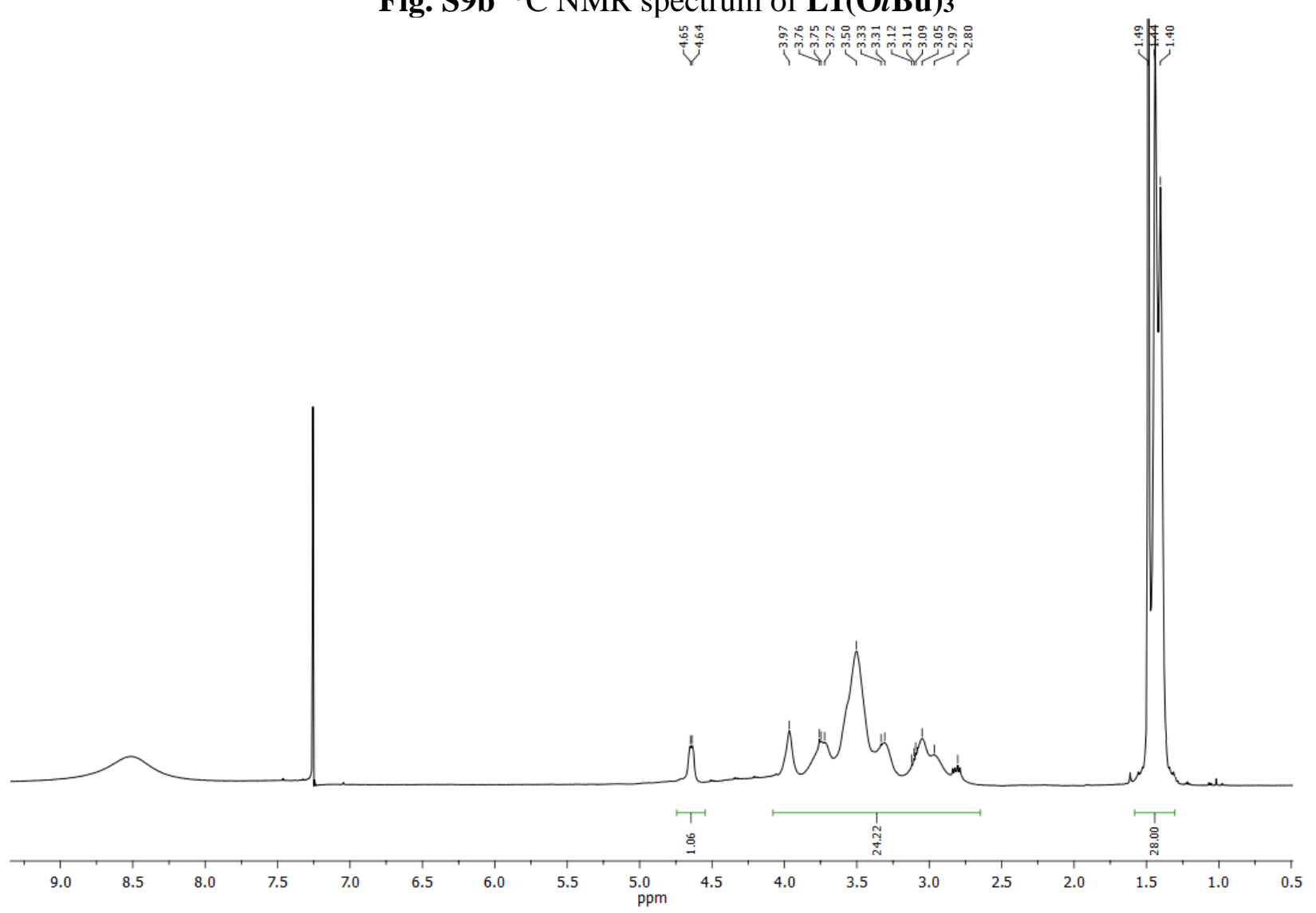

Fig. S10a ${ }^{1} \mathrm{H}$ NMR spectrum of $\mathbf{L 2}(\mathbf{O} t \mathbf{B u})_{3}$

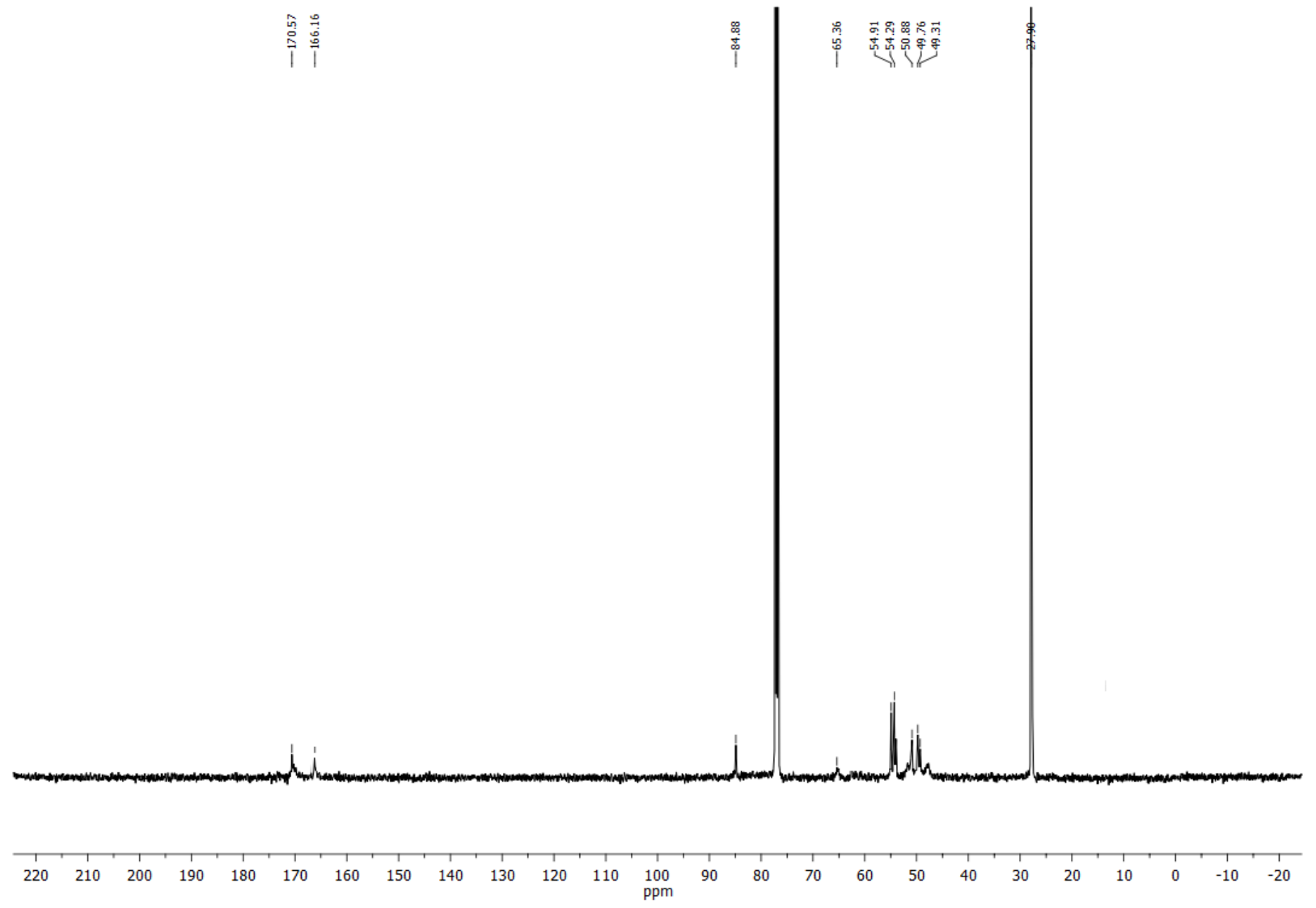

Fig. S10b ${ }^{13} \mathrm{C}$ NMR spectrum of $\mathbf{L 2}(\mathbf{O} t \mathbf{B u})_{3}$ 


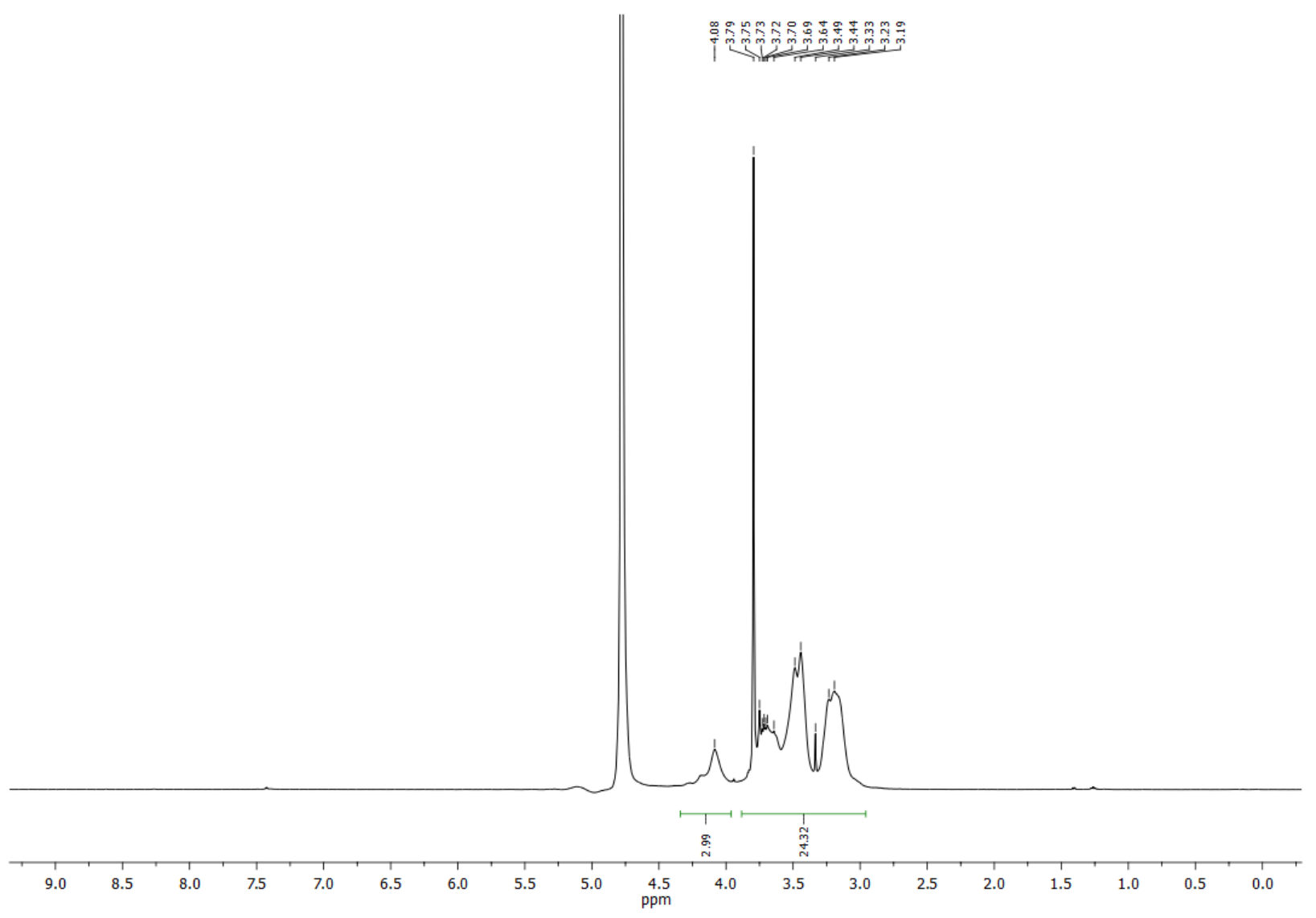

Fig. S11a ${ }^{1} \mathrm{H}$ NMR spectrum of $\mathbf{L 1}$

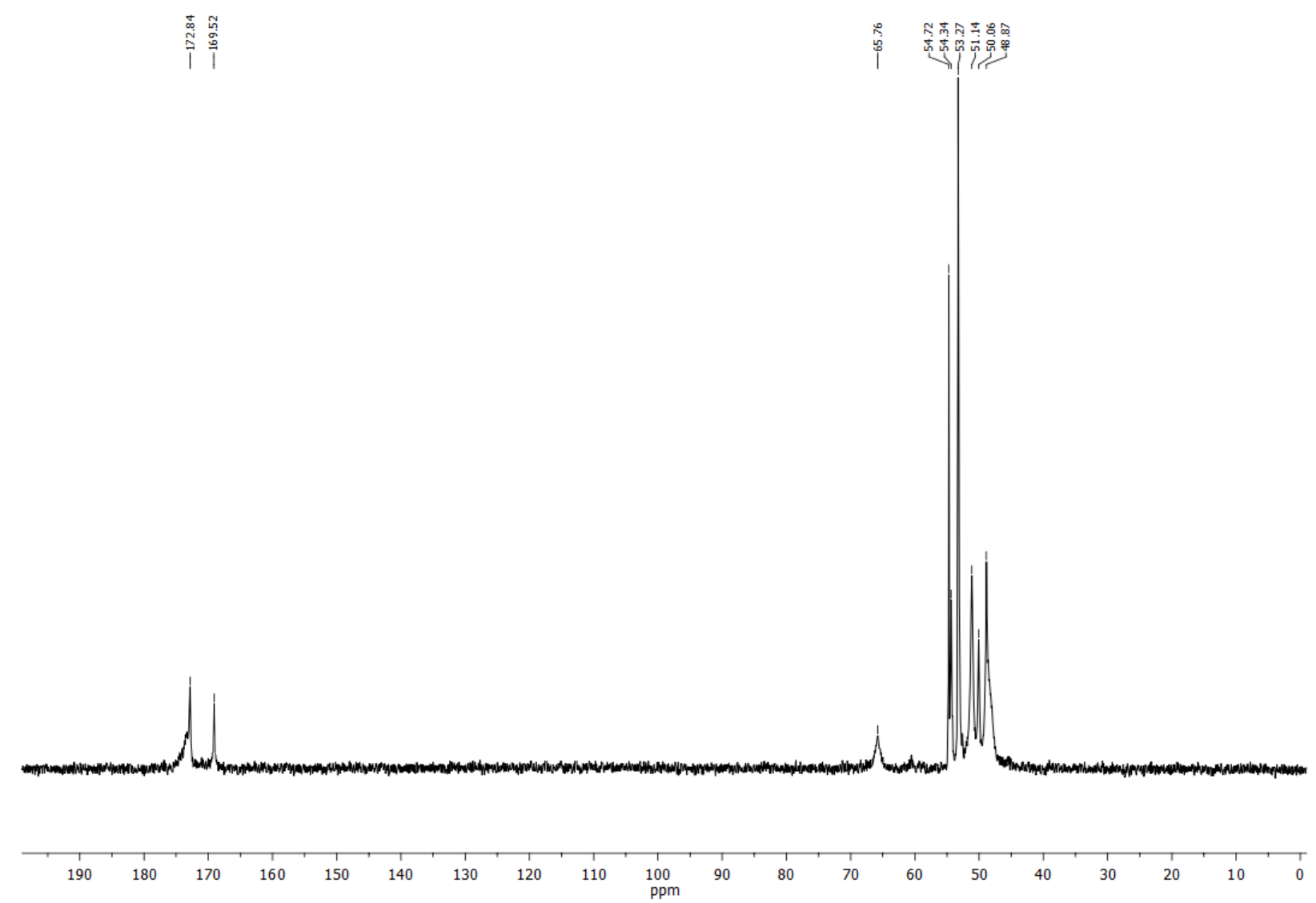

Fig. S11b ${ }^{13} \mathrm{C}$ NMR spectrum of $\mathbf{L 1}$ 


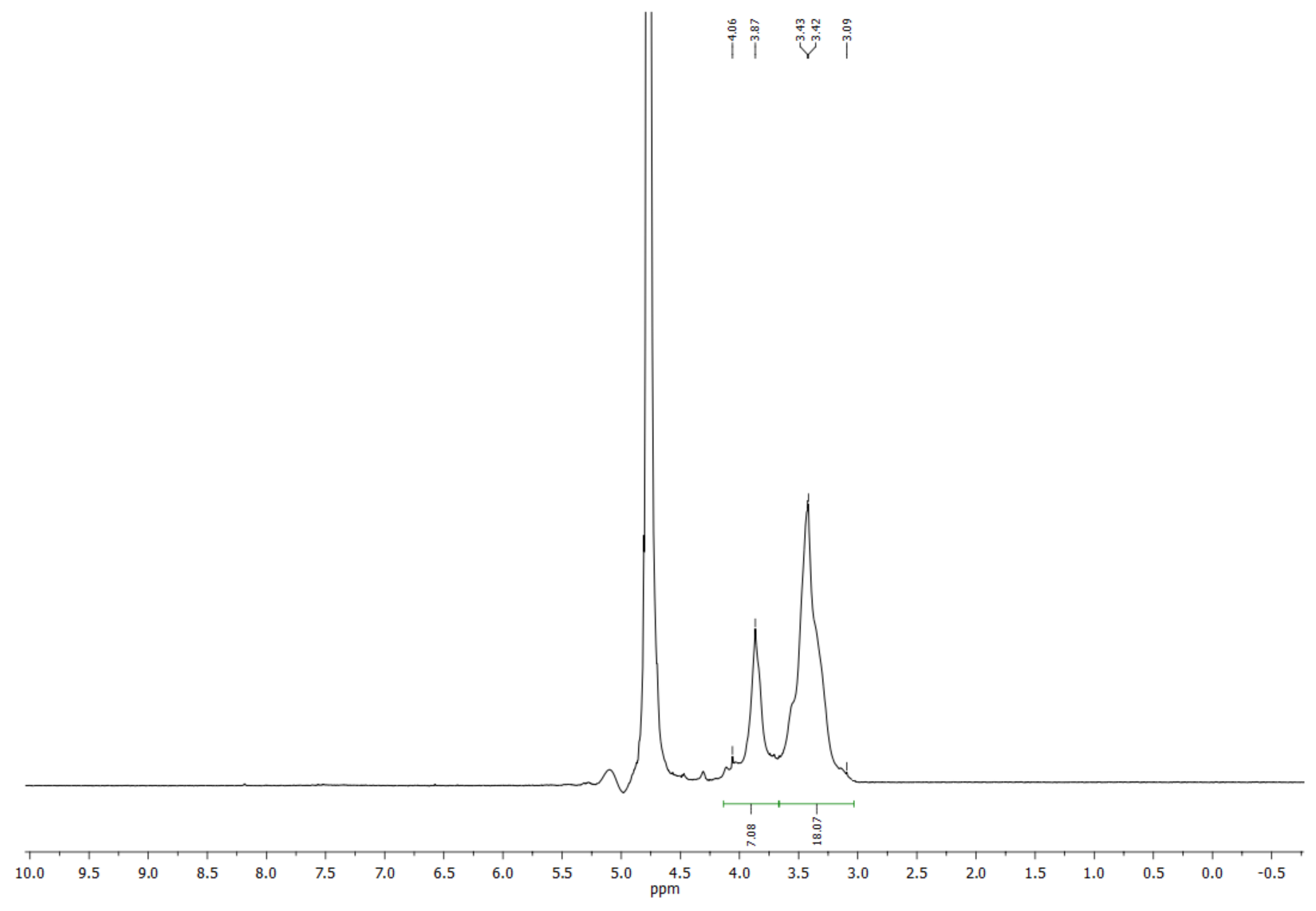

Fig. S12a ${ }^{1} \mathrm{H}$ NMR spectrum of $\mathbf{L} 2$
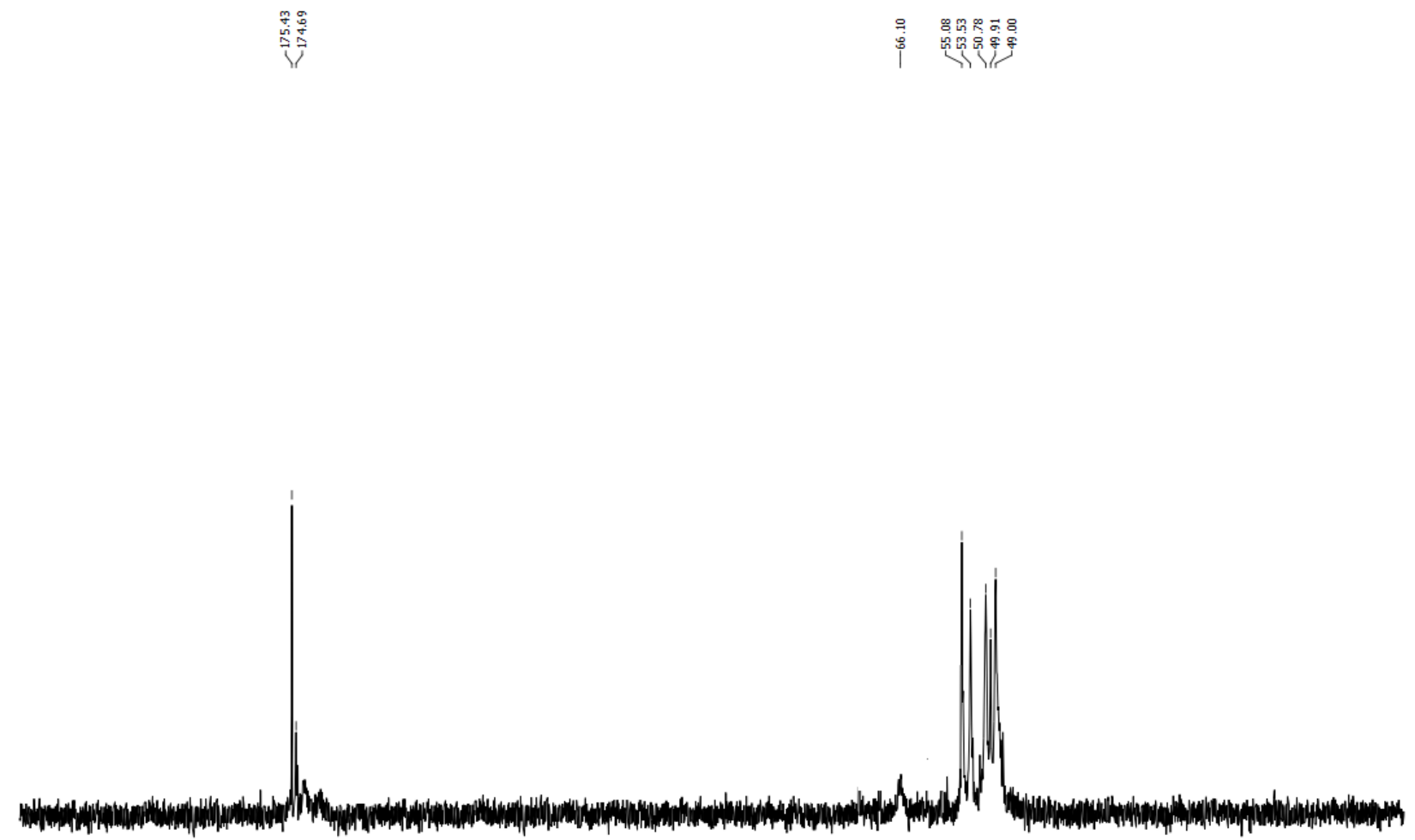

\begin{tabular}{rlllllllllllllllllllllllll}
\hline & 220 & 210 & 200 & 190 & 180 & 170 & 160 & 150 & 140 & 130 & 120 & 110 & 100 & 90 & 80 & 70 & 60 & 50 & 40 & 30 & 20 & 10 & 0 & -10 & -20
\end{tabular}

Fig. S12b ${ }^{13} \mathrm{C}$ NMR spectrum of $\mathbf{L 2}$ 

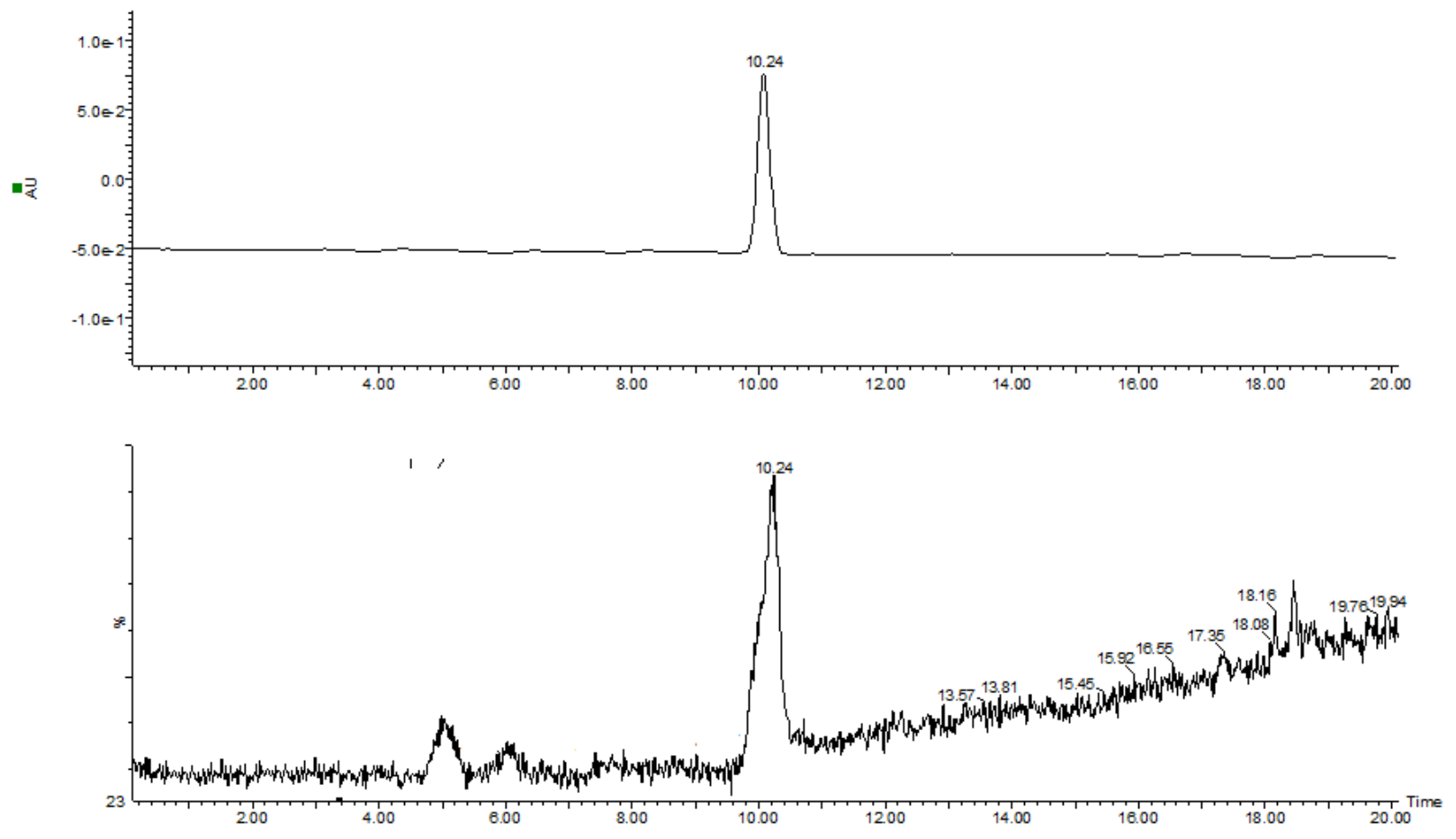

Fig. S13a HPLC-MS chromatogram of $\mathbf{L 1}$

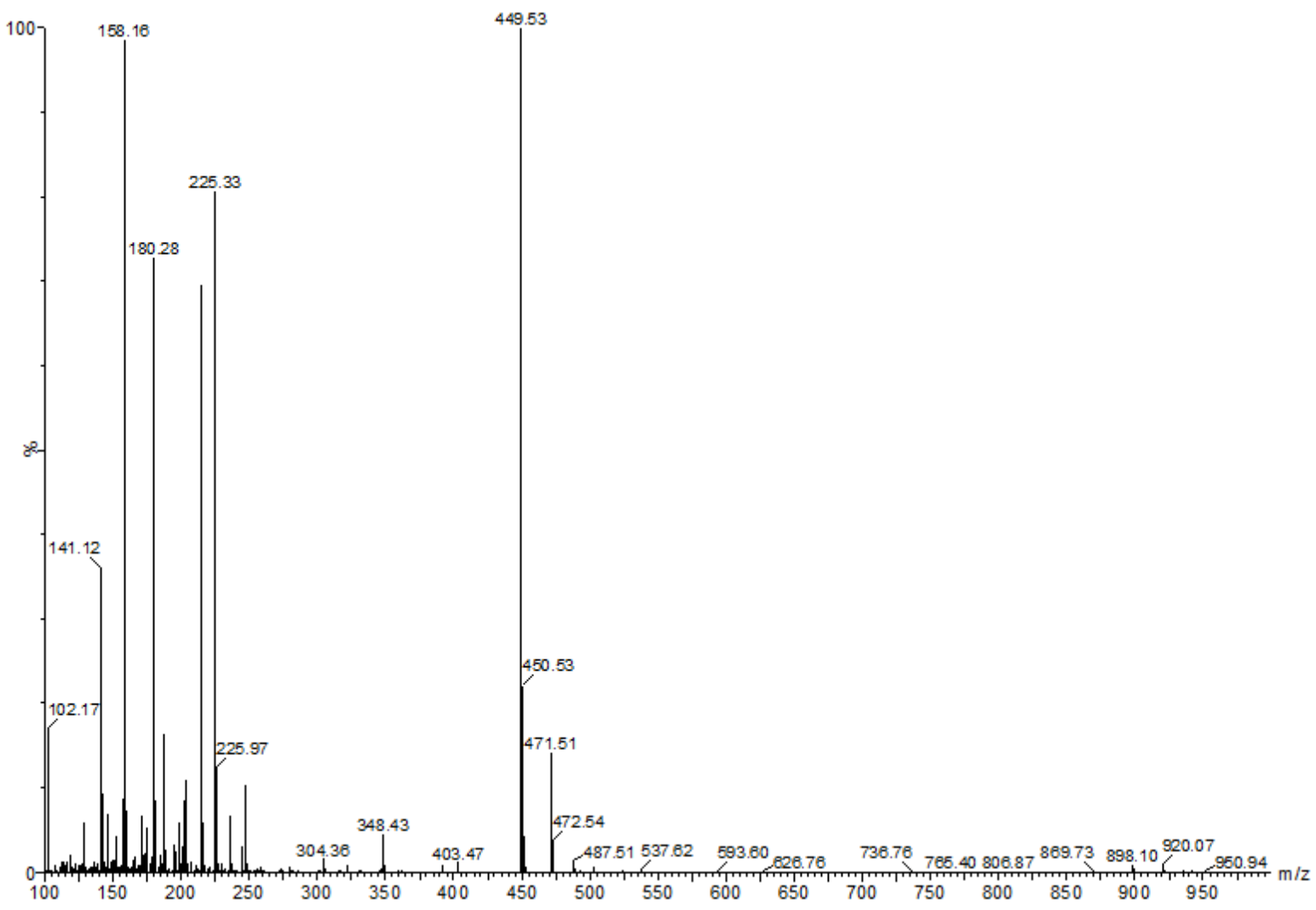

Fig. S13b ESI-MS spectrum of $\mathbf{L 1}$ 

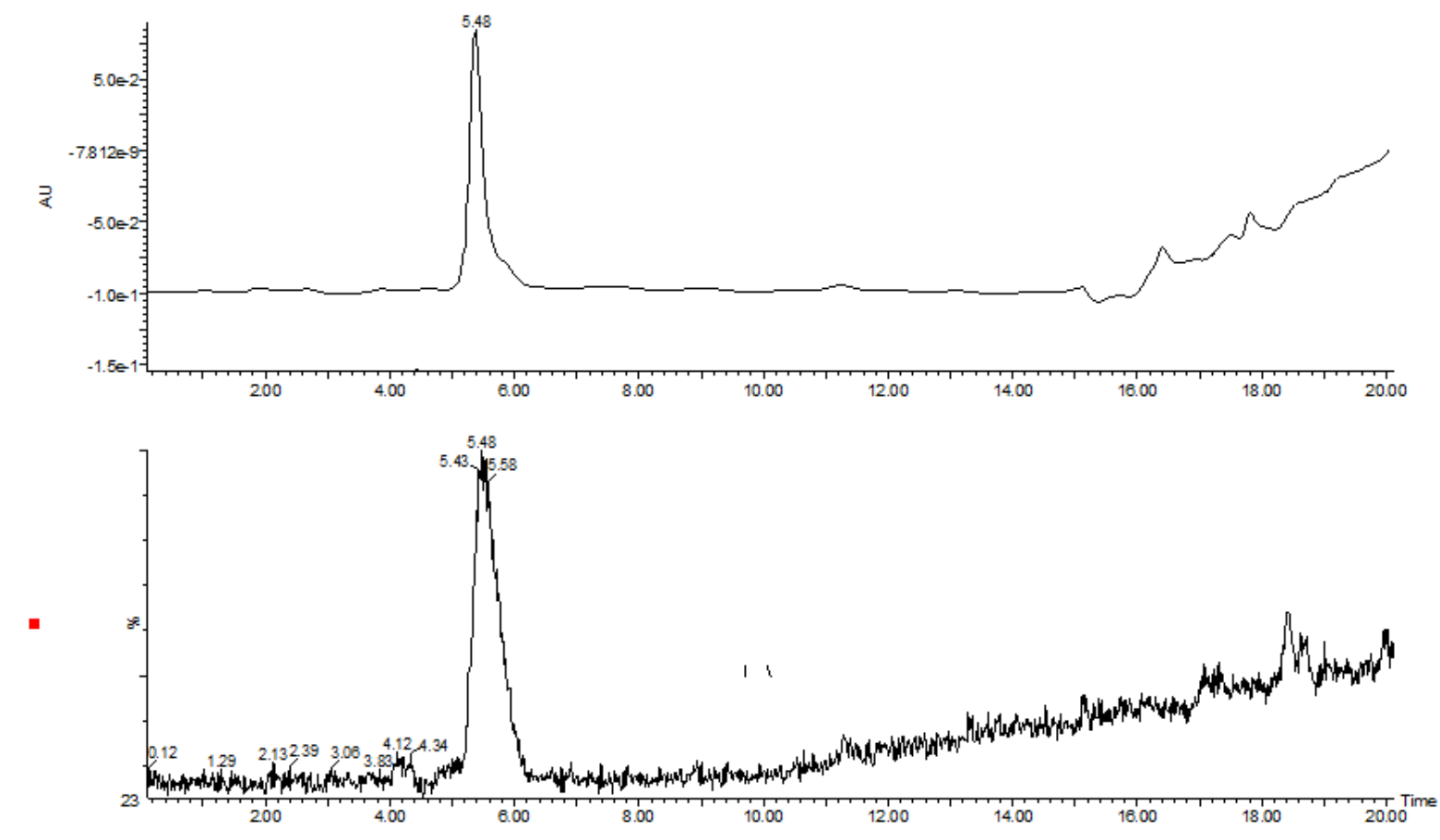

Fig. S14a HPLC-MS chromatogram of $\mathbf{L 2}$

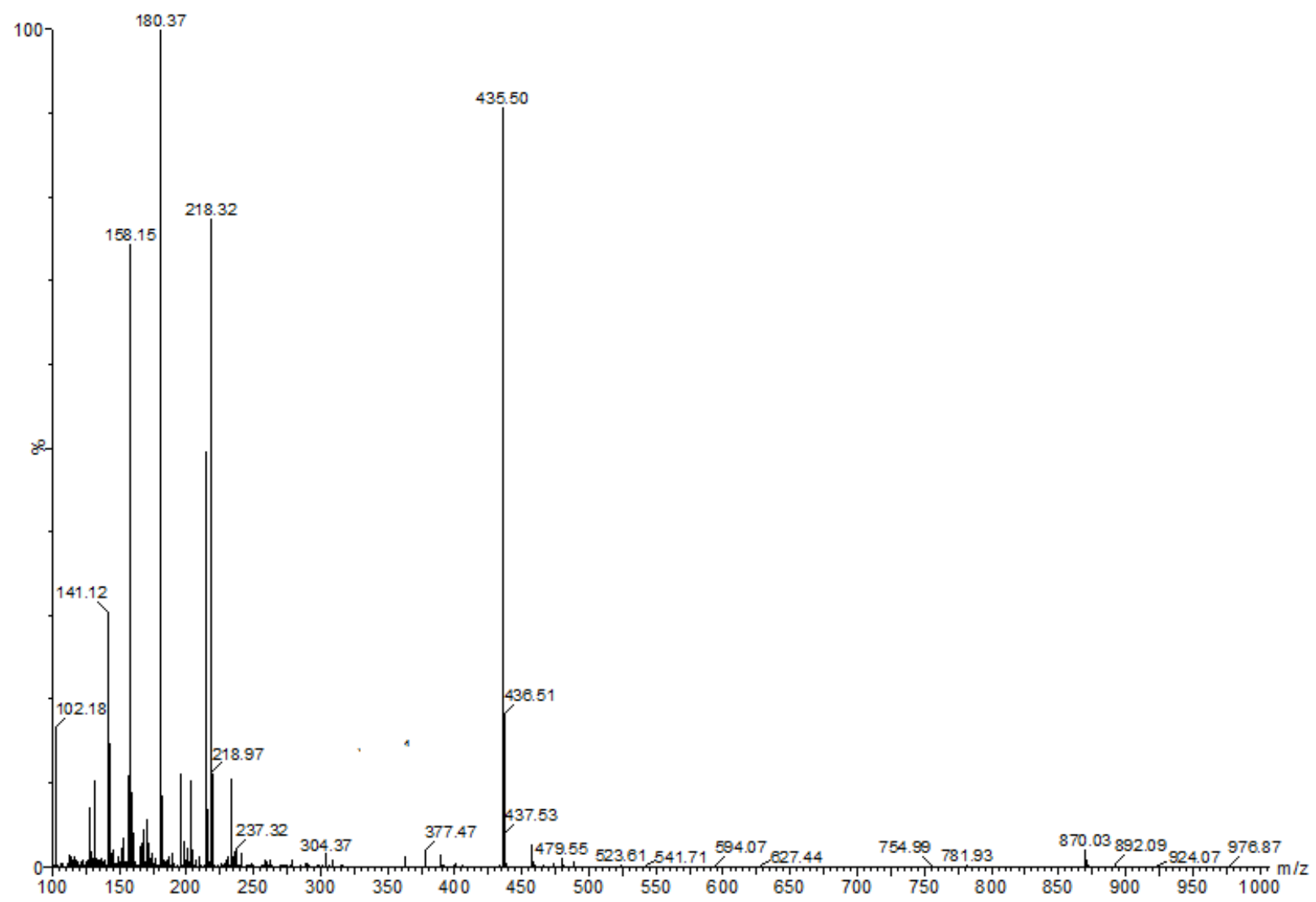

Fig. S14b ESI-MS spectrum of L2 

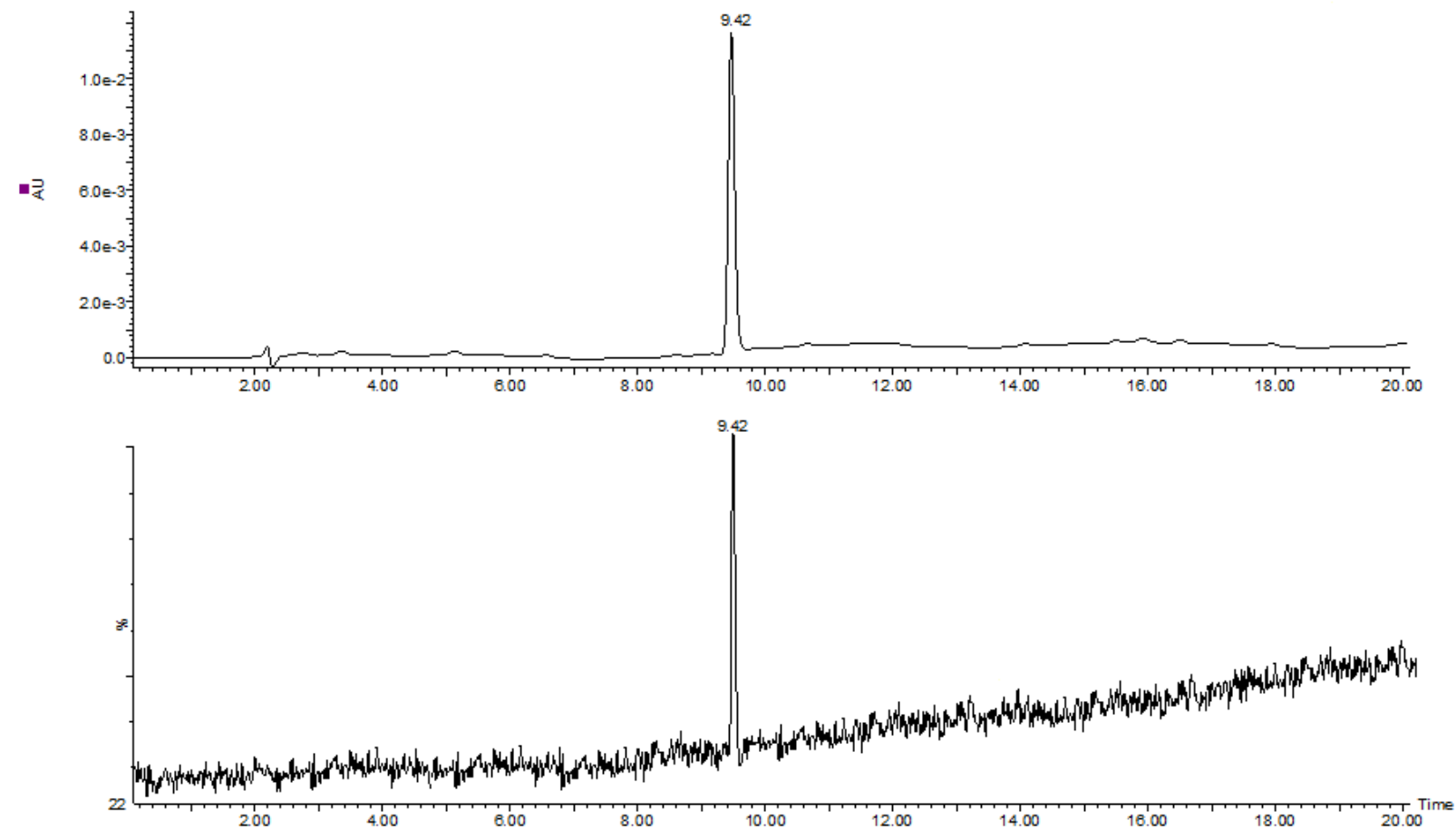

Fig. S15a HPLC-MS chromatogram of GdL1.

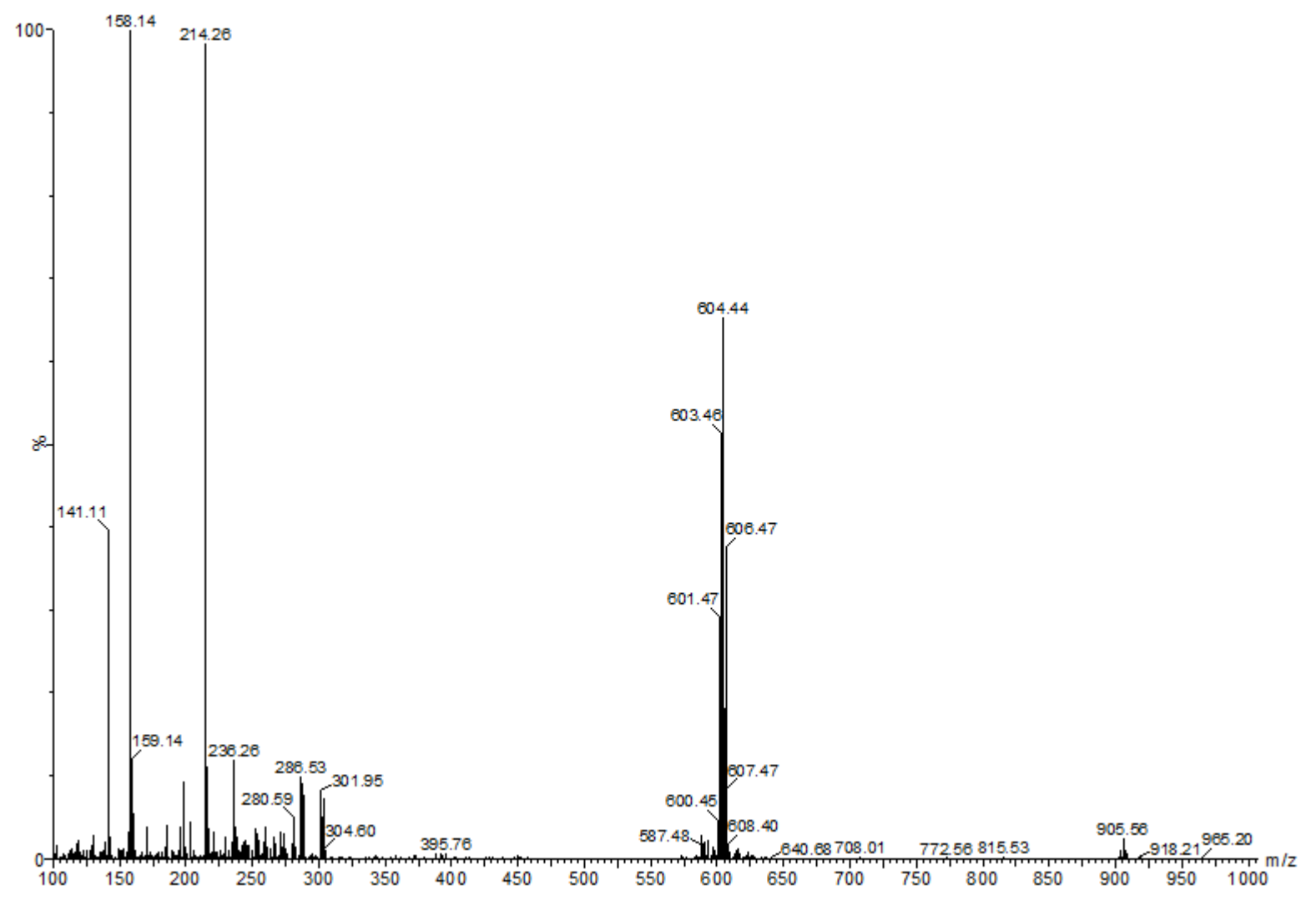

Fig. S15b ESI-MS spectrum of GdL1 

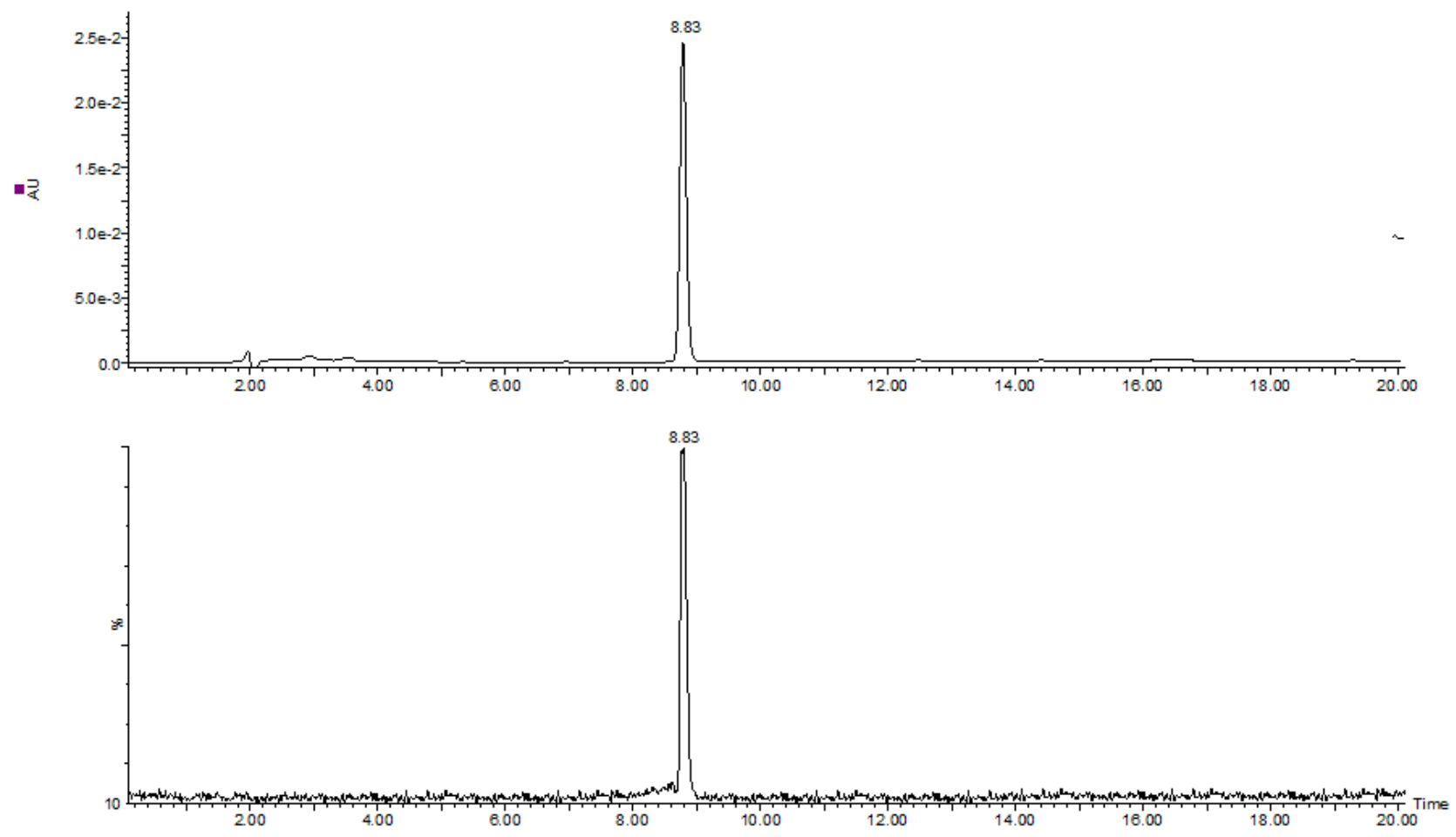

Fig. S16a HPLC-MS chromatogram of GdL2

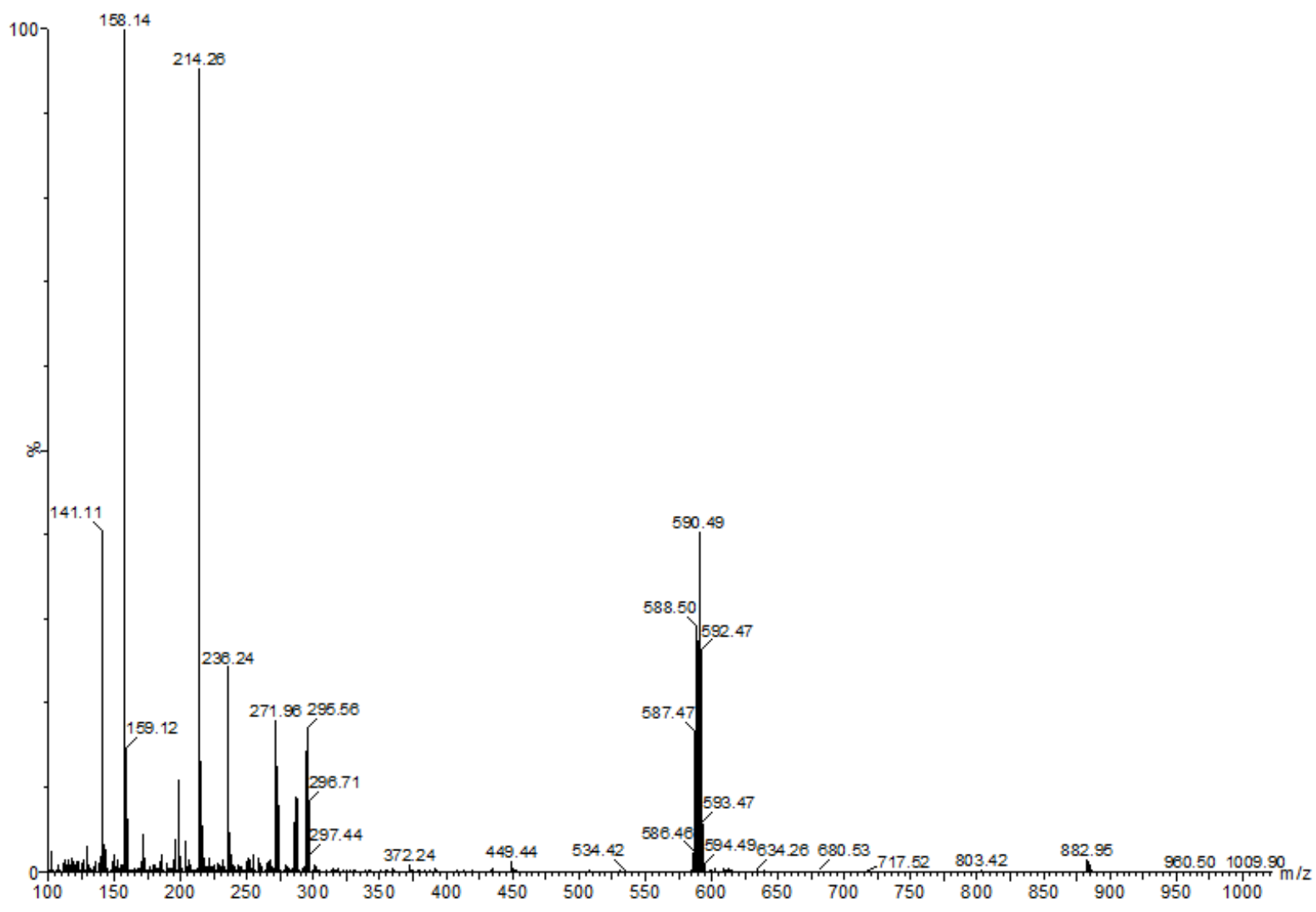

Fig. S16b ESI-MS spectrum of GdL2 


\section{References}

1) Desreux, J. F.; Merciny, E.; Loncin, M. F., Nuclear Magnetic-Resonance and Potentiometric Studies of the Protonation Scheme of 2 Tetraaza Tetraacetic Macrocycles. Inorg. Chem. 1981, 20 (4), 987-991.

2) Bianchi, A.; Calabi, L.; Giorgi, C.; Losi, P.; Mariani, P.; Paoli, P.; Rossi, P.; Valtancoli, B.; Virtuani, M., Thermodynamic and structural properties of $\mathrm{Gd} 3+$ complexes with functionalized macrocyclic ligands based upon 1,4,7,10-tetraazacyclododecane. J. Chem. Soc., Dalton Trans. 2000, (5), 697-705.

3) Takacs, A.; Napolitano, R.; Purgel, M.; Benyei, A. C.; Zekany, L.; Brucher, E.; Toth, I.; Baranyai, Z.; Aime, S., Solution structures, stabilities, kinetics, and dynamics of DO3A and DO3Asulphonamide complexes. Inorg. Chem. 2014, 53 (6), 2858-72.

4) Delgado, R.; da Silva, J. J., Metal complexes of cyclic tetra-azatetra-acetic acids. Talanta 1982, 29 (10), 815-22.

5) Tóth, É.; Király, R.; Platzek, J.; Radüchel, B.; Brücher, E., Equilibrium and kinetic studies on complexes of 10-[2,3-dihydroxy-(1-hydroxymethyl)-propyl]-1,4,7,10-tetraazacyclododecane-1,4,7triacetate. Inorg. Chim. Acta 1996, 249 (2), 191-199.

6) Tóth, É.; Brücher, E.; Lázár, I.; Tóth, I., Kinetics of Formation and Dissociation of Lanthanide(Iii)Dota Complexes. Inorg. Chem. 1994, 33 (18), 4070-4076.

7) Wu, S. L.; Horrocks, W. D., Kinetics of Complex-Formation by Macrocyclic Polyaza Polycarboxylate Ligands - Detection and Characterization of an Intermediate in the Eu3+-Dota System by Laser-Excited Luminescence. Inorg. Chem. 1995, 34 (14), 3724-3732.

8) Burai, L.; Fábián, I.; Király, R.; Szilágyi, E.; Brücher, E., Equilibrium and kinetic studies on the formation of the lanthanide(III) complexes, [Ce(dota)]- and [Yb(dota)]- (H4dota = 1,4,7,10tetraazacyclododecane-1,4,7,10-tetraacetic acid). J. Chem. Soc., Dalton Trans. 1998, (2), 243-248.

9) Moreau, J.; Guillon, E.; Pierrard, J. C.; Rimbault, J.; Port, M.; Aplincourt, M., Complexing mechanism of the lanthanide cations Eu3+, Gd3+, and Tb3+ with 1,4,7,10-tetrakis(carboxymethyl)1,4,7,10-tetraazacyclododecane (dota) - Characterization of three successive complexing phases: Study of the thermodynamic and structural properties of the complexes by potentiometry, luminescence spectroscopy, and EXAFS. Chem. - Eur. J. 2004, 10 (20), 5218-5232.

10) Perez-Malo, M.; Szabo, G.; Eppard, E.; Vagner, A.; Brucher, E.; Toth, I.; Maiocchi, A.; Suh, E.

H.; Kovacs, Z.; Baranyai, Z.; Rosch, F., Improved Efficacy of Synthesizing *M(III)-Labeled DOTA 
Complexes in Binary Mixtures of Water and Organic Solvents. A Combined Radio- and Physicochemical Study. Inorg. Chem. 2018, 57 (10), 6107-6117.

11) Leone, L.; Boccalon, M.; Ferrauto, G.; Fábián, I.; Baranyai Z.; Tei, L. Acid-catalyzed proton exchange as a novel approach for relaxivity enhancement in GdHPDO3A-like complexes, Chem. Sci., 2020, 11, 7829-7835

12) Lattuada, L.; Horváth, D.; Colombo Serra, S.; Fringuello Mingo, A.; Minazzi, P.; Bényei, A.; Forgács, A.; Fedeli, F.; Gianolio, E.; Aime, S.; Giovenzana, G. B.; Baranyai Z. Enhanced relaxivity of GdIII-complexes with HP-DO3A-like ligands upon the activation of the intramolecular catalysis of the prototropic exchange. Inorg. Chem. Front., 2021, 8, 1500-1510.

13) Kumar, K.; Tweedle, M. F.; Malley, M. F.; Gougoutas, J. Z., Synthesis, stability, and crystal structure studies of some $\mathrm{Ca} 2+, \mathrm{Cu} 2+$ and $\mathrm{Zn} 2+$ complexes of macrocyclic polyamino carboxylates. Inorg. Chem. 1995, 34 (26), 6472-6480.

14) Kumar, K.; Chang, C. A.; Francesconi, L. C.; Dischino, D. D.; Malley, M. F.; Gougoutas, J. Z.; Tweedle, M. F., Synthesis, Stability, and Structure of Gadolinium(III) and Yttrium(III) Macrocyclic Poly(amino carboxylates). Inorg Chem 1994, 33 (16), 3567-3575.

15) Clarke, E. T.; Martell, A. E., Stabilities of the alkaline earth and divalent transition metal complexes of the tetraazamacrocyclic tetraacetic acid ligands. Inorg. Chim. Acta 1991, 190 (1), 27 36.

16) Cacheris, W. P.; Nickle, S. K.; Sherry, A. D., Thermodynamic Study of Lanthanide Complexes of 1,4,7-Triazacyclononane-N,N',N"-Triacetic Acid and 1,4,7,10-TetraazacyclododecaneN,N',N",N'"-Tetraacetic Acid. Inorg. Chem. 1987, 26 (6), 958-960. 